\title{
Therapeutics with SPION-labeled stem cells for the main diseases related to brain aging: a systematic review
}

This article was published in the following Dove Press journal:

International Journal of Nanomedicine

II August 2014

Number of times this article has been viewed

\author{
Larissa T Alvarim ${ }^{1,3, *}$ \\ Leopoldo P Nucci ${ }^{2}$,* \\ Javier B Mamani' \\ Luciana C Marti' \\ Marina F Aguiar ${ }^{1,2}$ \\ Helio R Silva ${ }^{1,3}$ \\ Gisele S Silva \\ Mariana P Nucci-da-Silva ${ }^{4}$ \\ Elaine A DelBel ${ }^{5,6}$ \\ Lionel F Gamarra ${ }^{1-3}$ \\ 'Hospital Israelita Albert Einstein, São \\ Paulo, Brazil; ${ }^{2}$ Universidade Federal de \\ São Paulo, UNIFESP, São Paulo, Brazil; \\ ${ }^{3}$ Faculdade de Ciências Médicas da \\ Santa Casa de São Paulo, São Paulo, \\ Brazil; ${ }^{4}$ Departamento de Radiologia, \\ Hospital das Clínicas, Universidade \\ de São Paulo, Brazil; ${ }^{5}$ Universidade de \\ São Paulo-Faculdade de Odontologia \\ de Ribeirão Preto, São Paulo, Brazil; \\ ${ }^{6}$ NAPNA- Núcleo de Apoio a Pesquisa \\ em Neurociências Aplicadas, São \\ Paulo, Brazil \\ *These authors contributed equally \\ to this work
}

Correspondence: LF Gamarra Hospital Israelita Albert Einstein, Avenida Albert Einstein, no 627, Morumbi, São Paulo, SP 0565I-90I, Brazil Tel +55 I| 2।5 I 3727 Email lgamarra@einstein.br
Abstract: The increase in clinical trials assessing the efficacy of cell therapy for structural and functional regeneration of the nervous system in diseases related to the aging brain is well known. However, the results are inconclusive as to the best cell type to be used or the best methodology for the homing of these stem cells. This systematic review analyzed published data on SPION (superparamagnetic iron oxide nanoparticle)-labeled stem cells as a therapy for brain diseases, such as ischemic stroke, Parkinson's disease, amyotrophic lateral sclerosis, and dementia. This review highlights the therapeutic role of stem cells in reversing the aging process and the pathophysiology of brain aging, as well as emphasizing nanotechnology as an important tool to monitor stem cell migration in affected regions of the brain.

Keywords: iron oxide, dementia, stem cell, stroke, Parkinson's disease, sclerosis disease, brain aging

\section{Introduction}

\section{Brain aging}

Brain aging is a very complex biological process associated with a decline in sensory, motor, and cognitive function. Aging is not a disease, it is a regular physiological process that can be developed without associated diseases. When this occurs, the process is referred to as "successful aging". ${ }^{1}$ Aging brings the possibility of developing dementia as a result of the normal aging process, as has been postulated. ${ }^{1}$

It has been suggested that in an individual aged 120 years old without associated disease, the neocortical synapses would be reduced to the same levels found in Alzheimer's disease (AD) with a 40\% loss of intracerebral connectivity. This may result in senile dementia without amyloid plaques and neurofibrillary tangles, which characterizes $\mathrm{AD} .^{2}$ Although these data are controversial and clearly refer to very old age, which in fact lies at the upper limit of human longevity, they reveal the close relationship between aging and disease.

The successes of public and individual health achievements have led to a large increase in human life expectancy. In the early 1900s life expectancy was about 45 to 50 years; today, people aged 100 years or older are no longer considered unusual, and in some nations represent $2 \%$ of the population. ${ }^{3}$ This recent change in life expectancy has increased the number of elderly individuals.

The greater the number of older subjects living, the more individuals will experience changes associated with aging. In this sense, the incidence of diseases related to increasing age has also risen, especially stroke and neurodegenerative diseases, such as dementia, Parkinson's disease, and amyotrophic lateral sclerosis (ALS), which 
together affect approximately $3 \%$ of the population older than 65 years. $^{4}$

Thus, it is important to understand the mechanisms underlying longevity in human beings as well as the complex factors that make humans more vulnerable to neurodegenerative diseases. It is also important to study the therapeutics for restoring body and brain health during aging. 5,6

\section{Stroke}

Ischemic stroke is described as a sudden death of brain cells in a concentrated area, caused by an interruption of blood flow. This disease represents the third leading cause of death and the first cause of disability in developed countries. In addition, it is a neurological disease with a high mortality; 6.4 per $100,000 .^{7}$ There are different subtypes of stroke: ischemic stroke, caused by occlusion (temporary or permanent) of a blood vessel supplying the brain, and hemorrhagic stroke, caused by rupture of a blood vessel in the brain. Ischemic stroke is the most common type of stroke, accounting for $85 \%-90 \%$ of cases compared with hemorrhagic, $10 \%-15 \%$.

Thrombosis, embolism, or hypoperfusion may result in a restriction of blood flow to the brain, and may cause ischemic stroke, resulting in insufficient oxygen and glucose supply to support cellular homeostasis. This triggers several processes resulting in cell death by cytotoxicity or ionic imbalance. These processes lead to a significant increase in glutamatergic transmission, and as a consequence oxidative stress, inflammation, and apoptosis ${ }^{8-10}$ (Figure 1).

Currently, the main treatment for neural damage limitation in patients with ischemic stroke is the early administration of thrombolytic agents, but their use is often limited by a narrow therapeutic time window. ${ }^{8,11}$ Preclinical studies have been showing functional recovery after cell therapy. ${ }^{12-15}$

\section{Parkinson's disease}

Parkinson's disease is the second most common neurodegenerative disorder. The prevalence of this disease in industrialized countries affects roughly $0.3 \%$ of men, rises to $1 \%$ in the population older than 60 years and up to $4 \%$ in the population over 80 years. The mean age at diagnosis is around 60 years old, but $10 \%$ of cases classified as "early onset" show clinical symptoms in individuals between 20 and 50 years old.

Parkinson's disease affects multiple neurotransmitter systems and its cause is still unknown. The most accepted mechanism considered responsible for the classic motor features of the disease (bradykinesia, rigidity, tremor, and postural instability) is loss of dopaminergic neurons. These neurons are located in the substantia nigra and their degeneration leads to subsequent loss of endings in the basal ganglia (caudate, putamen [striatum], globus pallidus and subthalamic nucleus; Figure 1).

The treatments available nowadays provide only transitory symptomatic relief. In addition, there are serious complications that arise from chronic treatment with existing drugs. For example, the incidence of dyskinesia induced by levodopa is around $30 \%-50 \%$ after 5 years, and $60 \%$ after 10 years of treatment. ${ }^{16,17}$

Pre-clinical studies which had used stem cell-based therapy (by 6-OHDA [6-hydroxydopamine], MPTP [(1-methyl4-phenyl-1,2,3,6-tetrahydropyridine)] or rotenone) showed functional improvement without dyskinesia induction. ${ }^{18-25}$

\section{Multiple sclerosis and ALS}

Multiple sclerosis (MS), also called "disseminated sclerosis" is characterized by degeneration of the myelin sheath surrounding the brain and spinal cord axons, ${ }^{26}$ as shown in Figure 1. The main symptoms of axonal injury are characterized by motor and cognitive impairment. ${ }^{27}$

ALS, also known as Lou Gehrig's disease or Charcot, is a progressive and fatal neurodegenerative disease that affects 2.16 of 100,000 individuals. ALS is not a demyelinating disease, but rather characterized by degeneration of motor neurons (mainly pyramidal fasciculus in the lateral funiculus of the white matter of the spinal cord) that coordinate voluntary muscle movements observed in the clinical setting, which generate denervation by atrophy, such as loss of muscle mass with progressive difficulty in performing movements (akinesia), and muscle strength loss (atony). ${ }^{27}$

The actual arsenal of therapies available promotes delay/ blocks the process without restoration of functional loss in MS. However, in ALS the situation is more dire, because on average patients die 4 years after being diagnosed. ${ }^{28}$ Functional improvement was seen in preclinical ${ }^{29-33}$ and clinical studies $^{34}$ after cell therapy.

\section{Dementias}

Dementia is a progressive deterioration of cognitive functions, such as memory, language, and learning. ${ }^{35}$ Some neurodegenerative diseases such as Huntington's and Parkinson's disease can develop into dementia. ${ }^{36}$ However, AD is still the leading cause of dementia in elderly people, accounting for $60 \%-80 \%$ of cases. ${ }^{37}$

$\mathrm{AD}$ is a progressive neurodegenerative disease that can affect $60 \%$ of seniors over 80 years old. ${ }^{38}$ The cause of this disease remains unknown, but it is notorious that genetic 


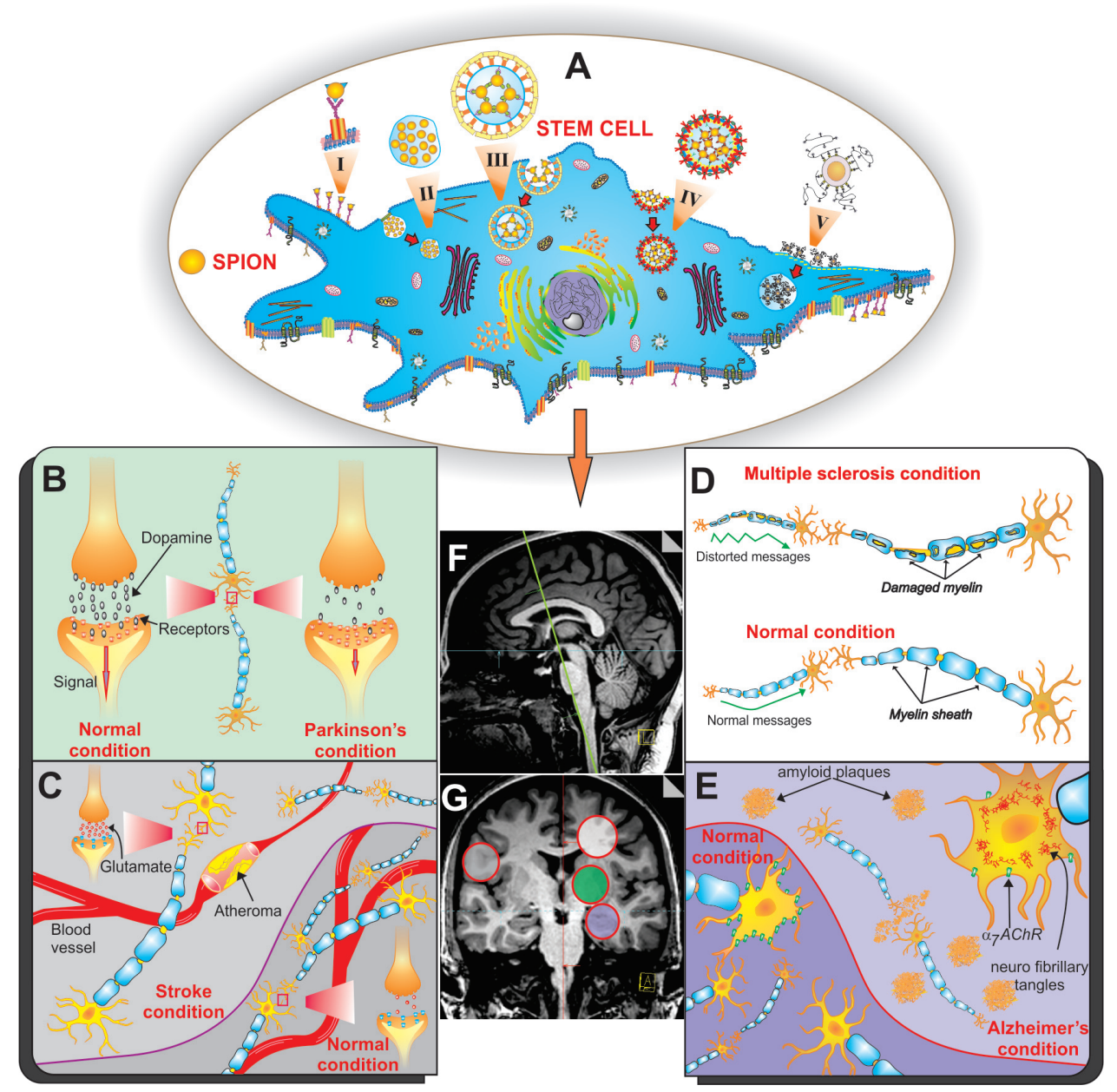

Figure I Schematic representation of a SPION labeled stem cell.

Notes: (A) The main routes of SPION internalization, were: i) mediated by membrane receptors, ii) independent of clathrin and caveolin, iii) clathrin-mediated, iv) caveolinmediated, and v) mediated by transfection poly-L-lysine agent. The labeled stem cell may be used in several situations or pathological conditions of the aging brain, such as: (B) Parkinson's disease, (C) stroke, (D) sclerosis, and (E) Alzheimer's disease. (F) Sagittal and (G) coronal MR image of the human brain; the gray circle corresponds with part $C$, the green circle with part $B$, the white circle with part $D$, and the purple circle with part $E$.

Abbreviations: SPION, superparamagnetic iron oxide nanoparticle; MR, magnetic resonance.

changes are found in less than $1 \%$ of cases..$^{39} \mathrm{AD}$ is associated with age and is characterized by deterioration of cognitive abilities, initially established by changes in recent memory. Disturbances in later stages of $\mathrm{AD}$ result in a generalized cognitive impairment, and patients become completely dependent on care givers' support. These stages often culminate in death. ${ }^{39}$

The brain of a patient who developed $\mathrm{AD}$ is shown in an illustrative manner in Figure 1G. This disease is characterized by the accumulation of senile plaques in the extracellular space of the cerebral cortex and hippocampus. Essentially, the plaque contains a small peptide called amyloid-beta $(\mathrm{A} \beta){ }^{40}$ $\mathrm{AD}$ is also characterized by intracellular neurofibrillary tangles shaped by hyperphosphorylated Tau protein, ${ }^{41}$ and reduced levels of nicotinic receptors (nAChRs) in regions that present protein aggregation. ${ }^{42}$

\section{Stem cell implications in diseases related to brain aging}

Stem cells are characterized by their ability to divide and give rise to identical daughter stem cells, and to differentiate into other cell types. ${ }^{43}$ Due to these features, stem cells are important during embryonic development for tissue formation and during adulthood to ensure tissue homeostasis, repair, and regeneration. ${ }^{44-46}$

The physiological loss of tissue homeostasis during life is typically connected to a progressive and extensive decline in the physical and cognitive performance of the whole organism, commonly referred to as aging. ${ }^{47,48}$ In addition to loss of stem cell turnover, aging is also caused by a decrease in the overall function of differentiated cells, which occurs due to the cell number and environmental factors including DNA damage, reduction in telomere length, oxidative stress, 
induction of stress response pathways, and production and accumulation of misfolded proteins. ${ }^{49-55}$

These functional changes may result in a number of disorders including neurological diseases and many other deleterious effects of age on the genome, epigenome, and proteome. Some of the functional changes arise in the cells autonomously and others are imposed by an age-related change in the local milieu or systemic environment. Notably, some changes, particularly epigenomic and proteomic, are potentially reversible, and both environmental and genetic interventions can result in the rejuvenation of aged stem cells. ${ }^{53,55}$ Such findings have profound implications for stem cell-based therapy of age-related diseases.

\section{Nanobiotechnology: possibilities}

Cell therapy is presented as a new therapeutic strategy, mainly when standard therapy is ineffective, but interpretation of results is often biased. A major challenge is the lack of consistent data on stem cells' survival, distribution, and repair process leading to functional recovery in in vivo experiments. ${ }^{56}$

To address these issues, a method of noninvasive cellular analysis is more efficient than conventional histopathological techniques, and provides unique information about cell behavior over time. ${ }^{57}$

In this sense, several imaging modalities are available, including computerized tomography (CT), positron emission tomography (PET), magnetic resonance imaging (MRI), computed tomography photon emission tomography (SPECT), optical imaging, and ultrasound. The advantages of MRI compared to other technologies include its high spatial resolution and no exposure of animals or patients to ionizing radiation, which is needed in CT, PET, and SPECT. ${ }^{58,59}$

The MRI "homing" analysis method of transplanted stem cells occurs by the use of contrast agent. Nowadays, several available magnetic nanoparticles exist, ${ }^{56}$ and the most commonly used one is iron oxide. ${ }^{60}$

The processes by which nanoparticles are internalized by cells are not fully elucidated; however, mechanisms of endocytosis well described in the literature are pointed out as the main routes of internalization, including: i) internalization mediated by membrane receptors, ii) internalization independent of clathrin and caveolin, iii) clathrin-mediated internalization, iv) internalization mediated by caveolin, and v) transfection agent mediated internalization by polyL-lysine (PLL), as shown in Figure 1.

It is necessary to understand how these endocytic processes can affect cellular homeostasis, including signal transduction, organization, and cell viability. ${ }^{60}$ Though, due to this cellular capacity, nanostructures can be inserted into a complex organism allowing cellular viewing, location, and tracking in vitro and/or in vivo.

Therefore, nanobiotechnology can offer many benefits to stem cell research, including cell tracking, which is currently the limiting factor for further advances in this field of science.

The aim of this review was to analyze publications on SPION (superparamagnetic iron oxide nanoparticle)labeled stem cells and their application in major diseases related to the aging brain, such as ischemic stroke, Parkinson's disease, sclerosis and dementias such as AD.

\section{Methods}

\section{Search strategy}

We searched publications between January 2000 and December 2013 indexed in PubMed, EMBASE, Web of Science, and Cochrane Library. For each selected disease a Boolean search strategy was developed with keywords and connectors (DecS/MeSH):

(i) Cerebral Ischemia AND Stroke: (((stem cell[MeSH Terms]) AND (iron oxide OR SPIO OR nanoparticle)) AND “cerebral ischemia”) OR (((stem cell[MeSH Terms]) AND (iron oxide OR SPIO OR nanoparticle)) AND stroke);

(ii) Parkinson's Disease: (((stem cell[MeSH Terms]) AND (iron oxide OR SPIO OR MRI)) AND "Parkinson disease"[MeSH Terms]) OR (((stem cell[MeSH Terms]) AND (iron oxide OR SPIO AND nanoparticle OR MRI)) AND 6 hydroxydopamine);

(iii) Multiple Sclerosis OR Amyotrophic Lateral Sclerosis: (((stem cell[MeSH Terms]) AND ("iron oxide" OR SPIO OR nanoparticle)) AND “multiple sclerosis") OR (((stem cell[MeSH Terms]) AND (iron oxide OR SPIO OR nanoparticle)) AND “amyotrophic lateral sclerosis") OR (((“stem cell”) AND “iron oxide”) AND “sclerosis");

(iv) Alzheimer's disease and dementia: (((stem cell[ $\mathrm{MeSH}$ Terms]) AND (iron oxide OR SPIO OR nanoparticle)) AND "Alzheimer disease") OR (((stem cell[MeSH Terms]) AND (iron oxide OR SPIO AND nanoparticle)) AND dementia).

\section{Data compilation and review}

In this review, five of the authors independently and randomly selected (in pairs) applied each disease using search strategies in the databases cited above.

HRS, GSS, MPN, and JBM searched for ischemic stroke; LTA, LFG, EADB, and LPN for Parkinson's disease; LCM, 
MFA, and LPN for MS and ALS; LTA, EADB, and LPN for $\mathrm{AD}$ and dementias. The analysis process and table plots were carried out by full consensus of peers, respecting the distribution above. In cases of disagreement, a third, independent author decided to add or subtract data.

Subsequently, JBM and LFG reviewed nanoparticles' characteristics, HRS and LTA stem cells' characteristics, LPN and LTA animal model characteristics and in vivo assay, finally LPN, LFG, and MPN neuroimaging methods used to assess therapeutic efficacy. In cases of disagreement, a third, independent author decided to add or subtract data.

\section{Selection criteria}

This review included only original articles written in English that had used SPION-labeled stem cells (SC/SPION) in preclinical models of stroke, Parkinson's disease, MS, ALS or AD and other dementias, published between 2000 and 2013.

Publications indexed in more than one database (duplicates), incomplete, conference presentations, book chapters, and non-English, as well as those that had not used SPION or SC were excluded from this review (Figure 2).

\section{Results}

After applying search strategies, 86 original articles were identified after expulsing the duplicated articles with selection of database. Of these, 44 publications were excluded for not including SPION and/or SC, nine were reviews, and one study ${ }^{61}$ which was written in Chinese. A total of 32 original articles satisfied the inclusion criteria: 20 on ischemic stroke, seven on Parkinson's disease and five on sclerosis (Figure 2).

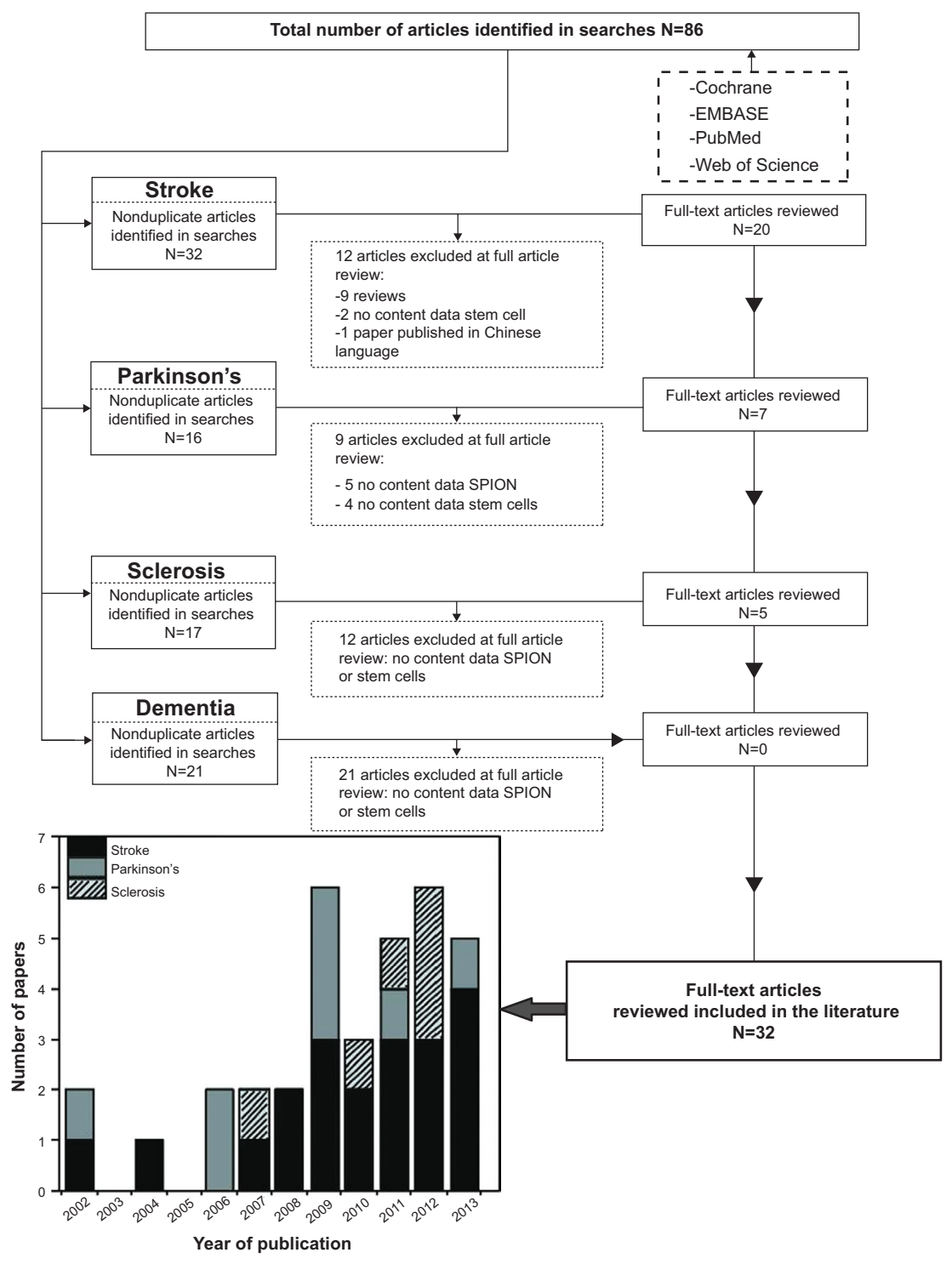

Figure 2 Flowchart of the article screening process for inclusion in this review.

Abbreviation: SPION, superparamagnetic iron oxide nanoparticles. 


\section{Physico-chemical characteristics of SPION}

Most of the iron oxide nanoparticles used in selected articles are commercialized (Table 1). Only eight articles ${ }^{13,19,21,62-65}$ described laboratory-synthesized nanoparticles ("in lab"). Among the 24 publications that used commercial nanoparticles, 16 studies ${ }^{12,14,20,22,25,29-32,66-72}$ used Feridex ${ }^{\circledR}$ or Endorem ${ }^{\mathrm{TM}}$ (Advanced Magnetic, Cambridge, MA, USA), five studies ${ }^{13,14,24,30,73}$ used Resovist ${ }^{\circledR}$ (Bayer Schering Pharma AG, Berlin, Germany), three studies ${ }^{14,30,74}$ used Sinerem ${ }^{\circledR}$ (Guerbet, Roissy, France), one study ${ }^{23}$ used very small superparamagnetic iron oxide particles (VSOP), one study $^{33}$ used Molday ION Rhodamine B (BioPAL Inc, Waltham, MA, USA), and one study ${ }^{72}$ used a group of commercial nanoparticles coupled with an other fluorophore, the FluidMag.

The majority of studies ${ }^{12,14,66-72}$ that used commercial SPION in stroke used Feridex ${ }^{\circledR}$ or Endorem ${ }^{\mathrm{TM}}$, four studies $^{13,14,72,74}$ used Resovist $^{\circledR}$ two studies ${ }^{14,74}$ used Sinerem $^{\circledR}$ one study ${ }^{72}$ used FluidMag-D ${ }^{\circledR}$, FluidMag-lipid ${ }^{\circledR}$, DEAEFluidMag ${ }^{\circledR}$, FluidMag- $\mathrm{P}^{\circledR}$ and FluidMag- $\mathrm{Q}^{\circledR}$ (all from Chemicell $\mathrm{GmbH}$, Berlin, Germany), and another study ${ }^{64}$ used iron fluorescent nanoparticles (excitation $480 \mathrm{~nm}$ and emission $250 \mathrm{~nm}$ ). In addition, 13 studies evaluated commercial nanoparticles, four studies evaluated nanoparticles synthesized by the group itself ("in situ"): i) Lee et al ${ }^{13}$ used nanoparticles synthesized from polymerization and coprecipitation processes. These processes were modified to obtain nanoparticles of different diameters $100-750 \mathrm{~nm}$; ii) Reddy et $\mathrm{al}^{62}$ used magnetic nanoparticles synthesized by sonochemistry method, followed by chitosana coating; iii) in a study by Wang et $\mathrm{al}^{63}$ the synthesis occurred in two steps: first, synthesis generated polystyrene nanocluster magnetite (PMNC) and second, it promoted PMNC coating with a layer of silica and rhodamine; iv) $\mathrm{Lu}$ et $\mathrm{al}^{75}$ used magnetic nanoparticles synthesized by the sonochemistry method. However, there was only one clinical trial ${ }^{65}$ that used magnetite nanobeads coated with dextran.

Among the six selected articles that evaluated the SC/ SPION effect in Parkinson's disease, five articles ${ }^{20,22-25}$ used commercial nanoparticles, three articles ${ }^{20,22,25}$ used Feridex ${ }^{\circledR}$, and Stroh et $\mathrm{al}^{23}$ used very small SPION-VSOP, ${ }^{69}$ another study $^{24}$ used Resovist ${ }^{\circledR}$. Besides these, two studies ${ }^{19,21}$ synthesized the nanoparticles ("in lab"). Bjorklund et al ${ }^{19}$ synthesized magnetite core coated with dipalmitoyl phosphatidic acid sodium (DPPA-Na) and ethylene oxide propylene oxide block copolymer (F108 ${ }^{\circledR}$; Bracco Research, Geneva, Switzerland). Jackson et $\mathrm{al}^{21}$ synthesized iron oxide

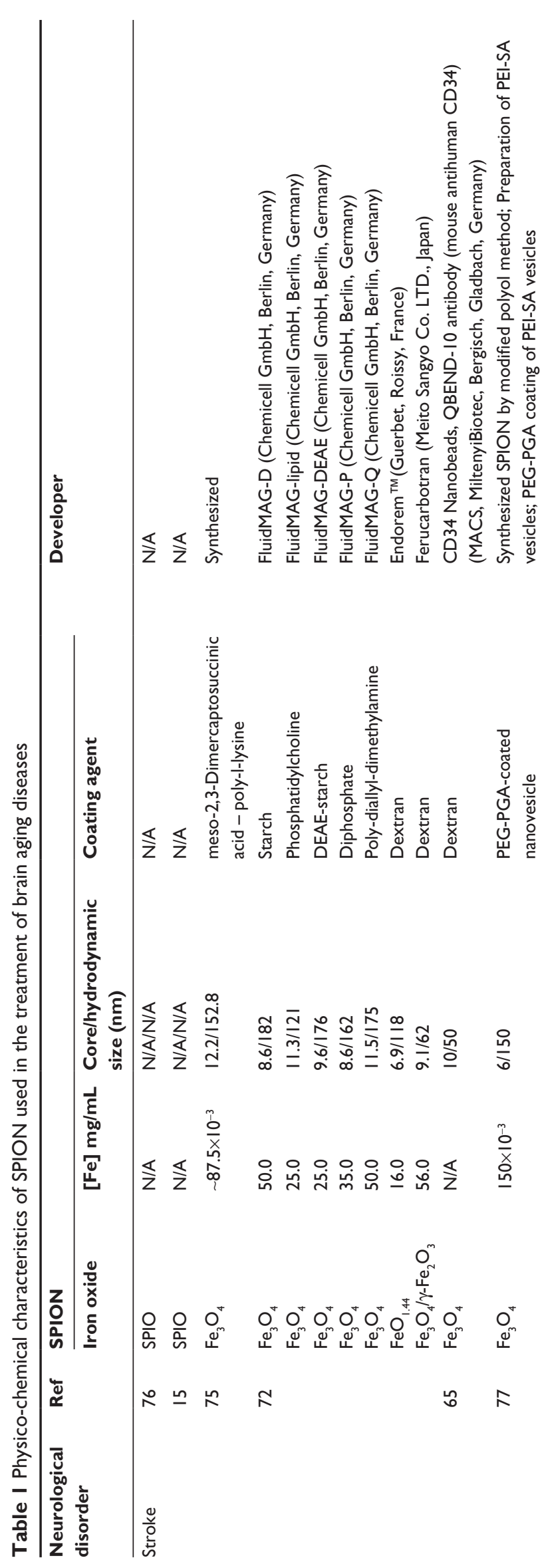




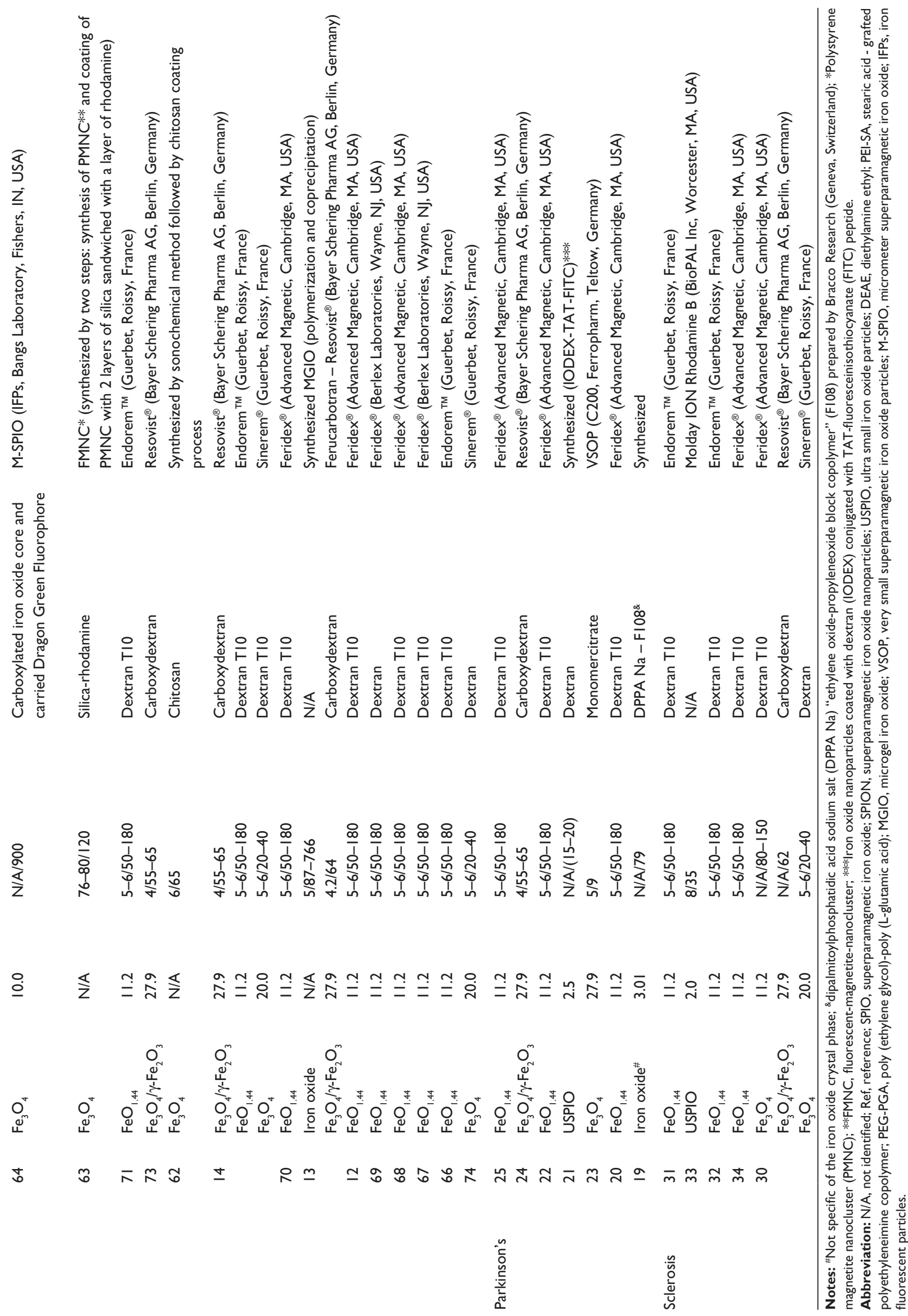


nanoparticles coated with dextran (IODEX) and coupled them with TAT-fluorescein peptide (FITC).

The nanoparticles used for ischemic stroke and Parkinson's disease studies were similar to those selected for MS, and most studies ${ }^{31,32,34}$ used Endorem ${ }^{\mathrm{TM}}$ (or Feridex ${ }^{\circledR}$ ). Only Politi et a ${ }^{30}$ used three types of nanoparticles $\left(\right.$ Endorem $^{\mathrm{TM}}$, Resovit ${ }^{\circledR}$ and Sinerem ${ }^{\circledR}$ ) in the same study, and Kim et $\mathrm{al}^{33}$ performed the study using Molday ION with Rhodamine B. All studies used commercial nanoparticles.

The majority of superparamagnetic iron oxide nanoparticles are coated by dextran (dextran T10 and carboxydextran) as identified in 21 articles. ${ }^{12-14,20,22,24,31,32,65,66-71,74}$ In addition to dextran, seven other types of SPION coatings were identified, such as starch, phosphatidylcholine, DEAE-diphosphate starch and poly-diallyl-dimethylamine in the Riegler et $\mathrm{al}^{72}$ study; carboxylated iron oxide core was seen in the Detante et $\mathrm{l}^{64}$ study, silica in the study by Wang et $\mathrm{al}^{63}$ monomer citrate in the study by Stroh et $\mathrm{al}^{23}$ and DPPA in the study by Bjorklund et al. ${ }^{19}$ There was one study ${ }^{62}$ that used both dextran and chitosan.

The physico-chemical features of the SPION used the most are: i) Feridex ${ }^{\circledR}$ also known as Endorem ${ }^{\mathrm{TM}}$, iron oxide nanoparticles with magnetite crystal phase, and mean core measuring 5-6 $\mathrm{nm}$ in diameter, and hydrodynamic diameters of 50-180 nm, coated with dextran 10 and provided in an iron concentration of $11.2 \mathrm{mg} / \mathrm{mL}$; ii) Resovist ${ }^{\circledR}$, iron oxide nanoparticles with magnetite crystal phase and maghemite core measuring on average $4 \mathrm{~nm}$ in diameter, and hydrodynamic diameters of 55-65 nm, coated with carboxydextran and provided at an iron concentration of $27.9 \mathrm{mg} / \mathrm{mL}$; iii) Sinerem $^{\circledR}$, iron oxide nanoparticles with magnetite crystal phase, core measuring 5-6 nm in diameter, and hydrodynamic diameters of $20-40 \mathrm{~nm}$, coated with dextran 10 and provided at an iron concentration of $20.0 \mathrm{mg} / \mathrm{mL}$.

In vitro experiments for stem cell labeling Regarding the analysis of the SPION cell labeling process by the 32 selected articles, the majority (19) used mesenchymal stem cells (MSC), six articles ${ }^{12,19,23,33,66,74}$ used embryonic stem cells, five articles ${ }^{20,25,30,70,76}$ used neural stem cells, one article ${ }^{65}$ used hematopoietic stem cells, and the other article $^{31}$ used amniotic fluid-derived stem cells (Table 2).

The use of a transfection agent and a culture medium to optimize the stem cell labeling process with SPION is usual. In 15 publications the transfection agent was used, of these studies, 12 used PLL and Dulbecco's Modified Eagle's Medium (DMEM) as their culture

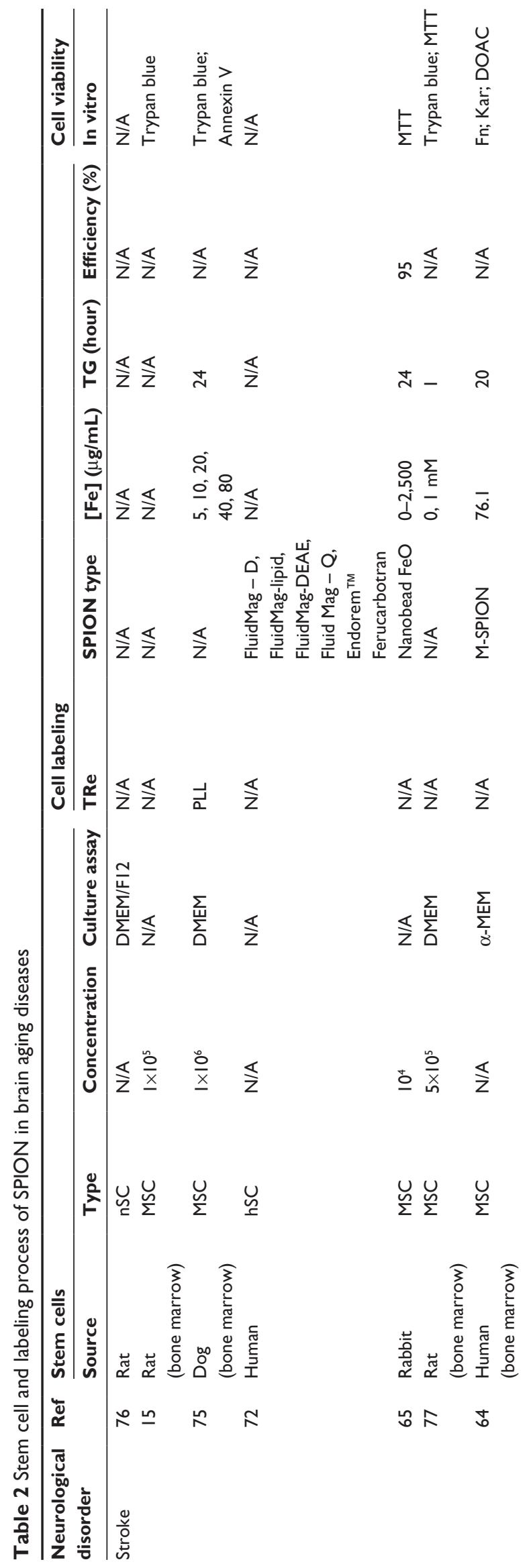




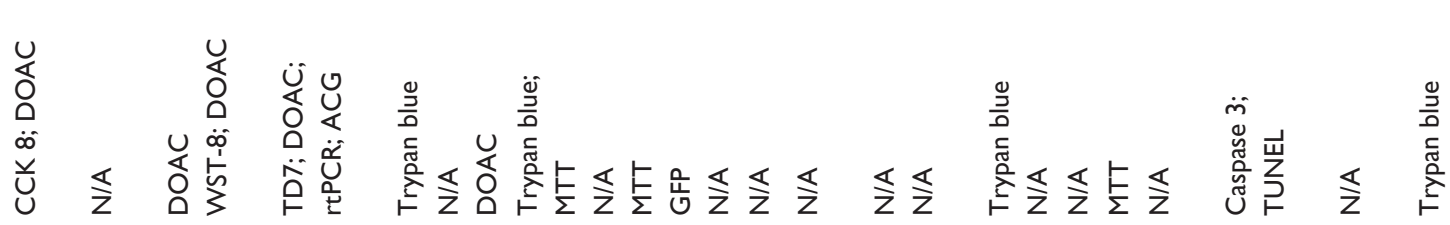

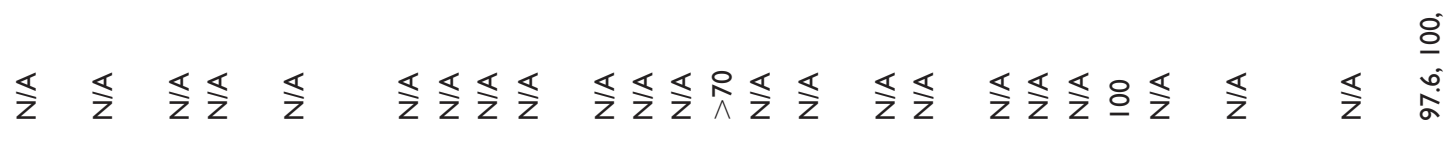

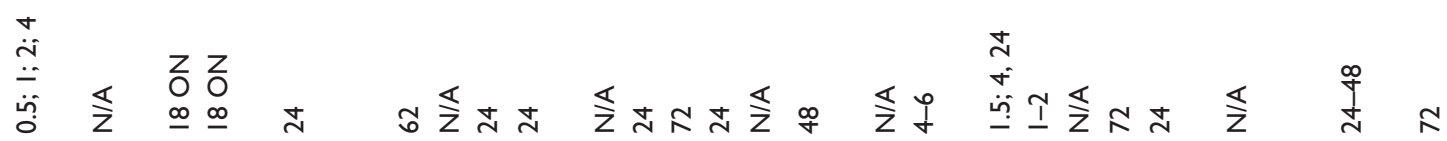

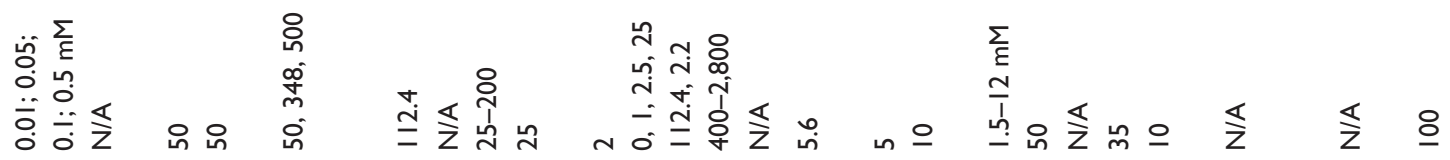

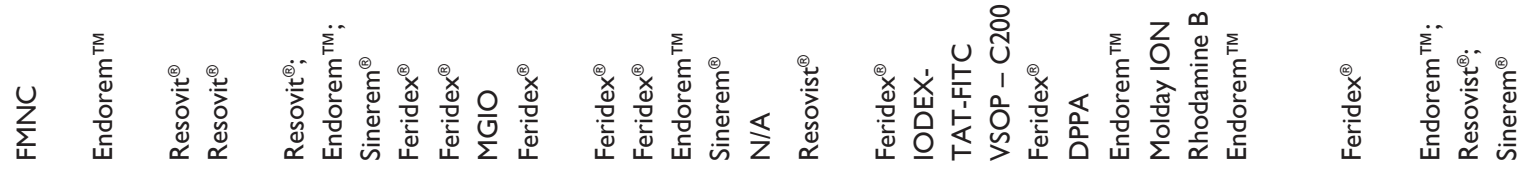

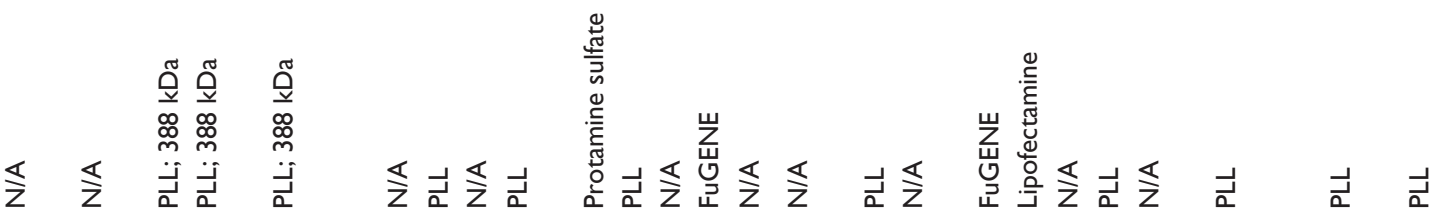

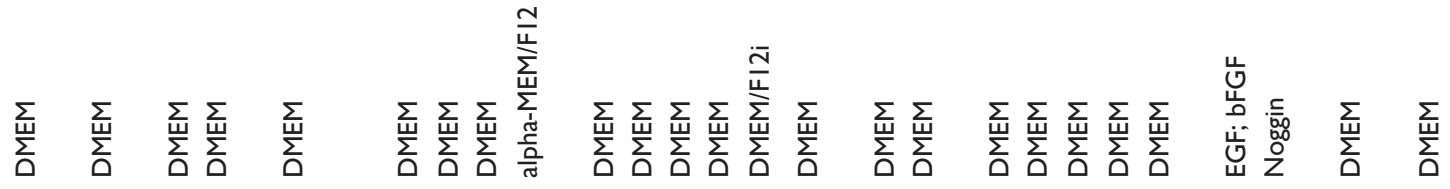

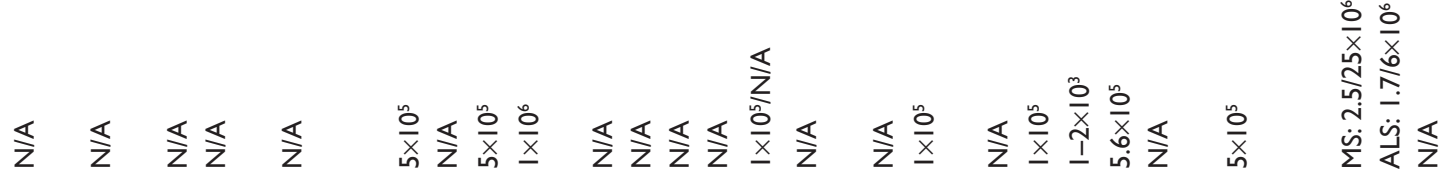

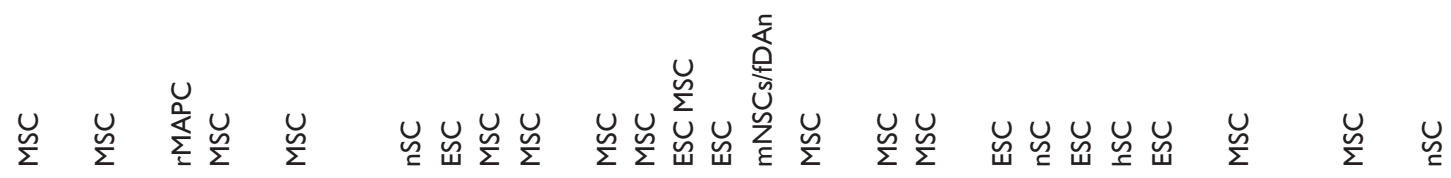

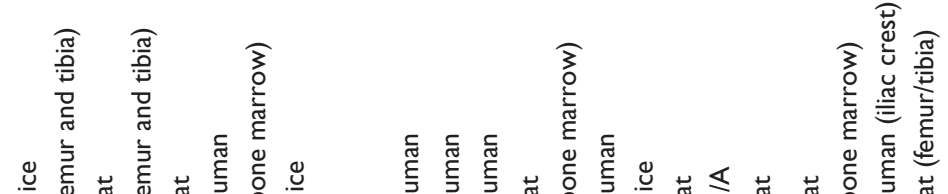

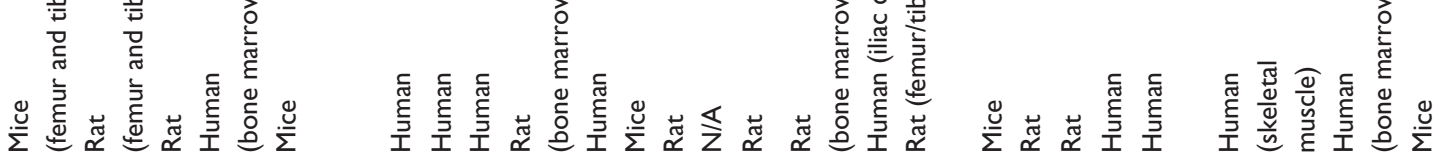

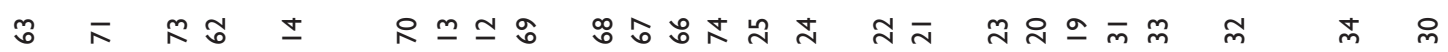

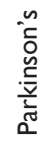

$\frac{\stackrel{n}{0}}{\frac{0}{\tilde{u}}}$

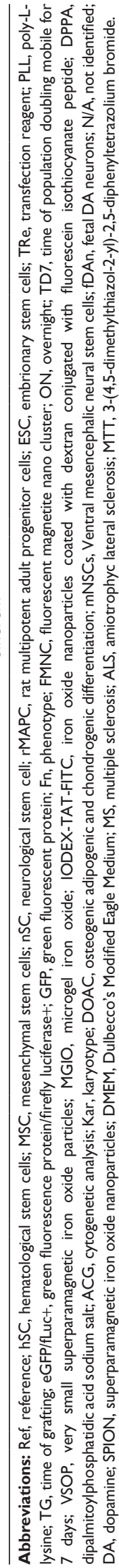


medium. The concentration of transfected cells ranged from $10^{3}$ in the Bigini et $\mathrm{al}^{31}$ study, to $25 \times 10^{6}$ in the Karussis et $\mathrm{al}^{34}$ study. Whereas the SPION concentration ranged from from $0.01 \mu \mathrm{g} / \mathrm{mL}$ in Wang et a ${ }^{63}$ study, to $2,800 \mu \mathrm{g} / \mathrm{mL}$, in the Hoehn et $\mathrm{al}^{74}$ study. Thus, the incubation period of the SPION with the stem cells ranged from 1 hour in the Yang et $\mathrm{al}^{20}$ study, to 72 hours in three other studies, ${ }^{30,31,66}$ but most studies $(75 \%)$ used 24 hours.

The labeling efficiency was mentioned in only four studies, ${ }^{22,30,72,74}$ and ranged from $15.4 \%$ in the Canzi et $\mathrm{al}^{32}$ study, to $100 \%$ in the Bigini et $\mathrm{al}^{31}$ study, of cells effectively labeled with SPION. Cell viability analysis after labeling was performed in only nine studies, ${ }^{15,23,30,31,67,69,70,75}$ of which 16 studied some method of analysis, using the MTT assay and/or trypan blue, and also testing cells' differentiation into mesodermal lineages as osteogenic, adipogenic, and chondrogenic in five of the 32 studies. ${ }^{12,14,62,64,73}$ After analysis of these parameters for each disease related to brain aging, a small variation between the sources was observed, cell types, and methods for SPION labeling.

\section{Stroke}

Among 20 stroke publications, most of them used MSC (Table 3). ${ }^{13-15,62-64,66,68,69,71,72,75}$ Only three articles ${ }^{12,66,74}$ used embryonic stem cells, three articles ${ }^{12,70,76}$ used neural lineages, one article ${ }^{65}$ used hematopoietic stem cells from peripheral blood, and one article ${ }^{73}$ used adult progenitor cells. Of these 13 articles that used MSC, five articles ${ }^{14,66,68,72,76}$ did not specify the cell source, in five articles ${ }^{15,62,64,69,75}$ the stem cells were derived from bone marrow, one article ${ }^{13}$ used fetal MSC, and two articles ${ }^{63,71}$ used MSC derived from tibia and femur.

Six studies used human cells, ${ }^{12,13,62,64,65,70}$ three studies $^{14,63,67}$ used mouse cells, four studies ${ }^{66,69,71,73}$ used rat cells, one study ${ }^{72}$ used rabbit cells, and one study ${ }^{74}$ did not specify the animal source. Only four studies ${ }^{13,69,70,72}$ revealed cell concentration. Walczak et $\mathrm{al}^{69}$ used the highest concentration among the identified studies $\left(1 \times 10^{6}\right)$, two other studies ${ }^{13,70}$ used the cellular concentration of $5 \times 10^{5}$, and the study done by Riegler et al, ${ }^{72}$ used only $10^{4}$ cells.

These cells were cultured mostly in DMEM basal medium. ${ }^{12,13,62,66,67,70,71,74,76}$ Among studies, two ${ }^{12,76}$ used DMEM with F12 and another study ${ }^{69}$ used $\alpha$-MEM medium with F12. Detante et al ${ }^{64}$ used only $\alpha$-MEM without F12 supplementation. Specific medium for MSC was used in one study. ${ }^{72}$ A total of six studies did not specify medium. ${ }^{14,15,63,65,68,73}$

Again analyzing the process of SPION stem cell labeling, most studies used a transfection agent for particle internalization. ${ }^{12,14,62,67-69,73,74}$ Among those, six studies ${ }^{12,14,62,67,69,73}$ used PLL, one study ${ }^{74}$ used FuGENE ${ }^{\circledR}$ (Promega Corporation, Fitchburg, WI, USA) and one study ${ }^{68}$ used protamine sulfate. Serum deprivation for particles' internalization was applied in one study. ${ }^{72}$ The most prevalent SPION concentration identified in six studies ${ }^{13,14,66,67,72,74}$ was around $374 \mu \mathrm{g} / \mathrm{mL}$, but concentrations of iron $\mu \mathrm{g} / \mathrm{mL}$ ranged from 0 in the Riegler et $\mathrm{al}^{72}$ study to $2,800 \mathrm{mg} / \mathrm{mL}$ of $\mathrm{Fe}$ in the Hoehn et $\mathrm{al}^{74}$ study.

The average incubation time for stem cells with SPION was 24 hours, the shortest period (1 hour) of incubation was performed by Wang et al, ${ }^{63}$ and the longest ( 72 hours) by Jendelová et al ${ }^{66}$ and Song et al. ${ }^{70}$

After the SPION labeling/internalization process described previously, cells were analyzed for viability and labeling efficiency. Several studies ${ }^{13,14,62-64,66}$ analyzed the differentiation of cells into osteogenic, adipogenic, and chondrogenic lineages, and four studies ${ }^{15,69,70,75}$ analyzed the viability by trypan blue exclusion. Only two studies ${ }^{72,74}$ referred to the relative value of labeled cells. The results of these two studies showed labeling efficiency up to $70 \%$. In the Riegler et $\mathrm{al}^{72}$ study, labeling reached about $95 \%$ of SPION labeled cells.

\section{Parkinson's disease}

Out of a total of seven selected studies on SPION labeled stem cells in Parkinson's disease experimental model (Table 4), three studies ${ }^{21,22,24}$ used MSC. Of these three studies, two used bone marrow as a source of MSC. ${ }^{22,24}$ Two of the remaining four articles used neural stem cells ${ }^{20,25}$ and two used embryonic stem cells. ${ }^{19,23}$ One study ${ }^{22}$ used stem cells of human origin, and the other studies ${ }^{19-21,23-25}$ used rodent cells; five studies ${ }^{19-21,24,25}$ used rats stem cells, and one study ${ }^{23}$ used mouse stem cells.

Culture medium used in all studies was the basic DMEM. However, two studies ${ }^{20,25}$ supplemented DMEM with F12 medium. Two articles ${ }^{20,21}$ stated the cell concentration required for SPION labeling, $1 \times 10^{5}$ cells.

Six of seven studies used commercially available particles in the SPION labeling process. Two studies ${ }^{20,22}$ used Feridex $^{\circledR}$ and the others ${ }^{19,21,23,24}$ adopted DPPA20, VSOP70, IODEXTAT-FITC or Resovist ${ }^{\circledR}$. Among the selected studies, four ${ }^{20,21,23,24}$ specified the incubation period of cells with particles, approximately 10 hours; incubation periods ranged from 1 hour in Yang et al ${ }^{20}$ study, to 48 hours in Guo et al ${ }^{24}$ study. The concentration of the nanoparticles used in selected studies was between $5 \mu \mathrm{g} / \mathrm{mL}$ in Sadan et $\mathrm{al}^{22}$ study, and $50 \mu \mathrm{g} / \mathrm{mL}$ in Yang et $\mathrm{al}^{20}$ study. 


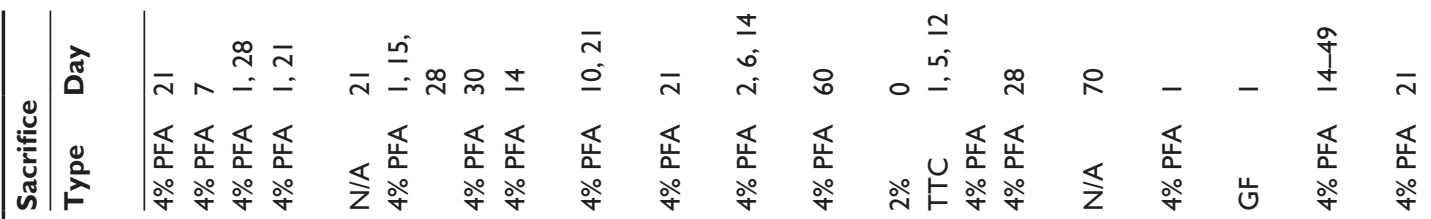

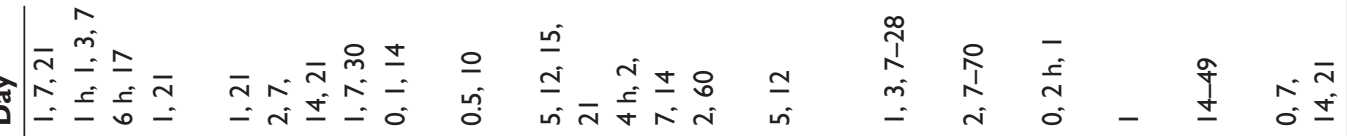

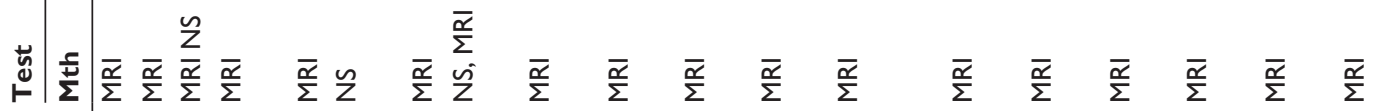

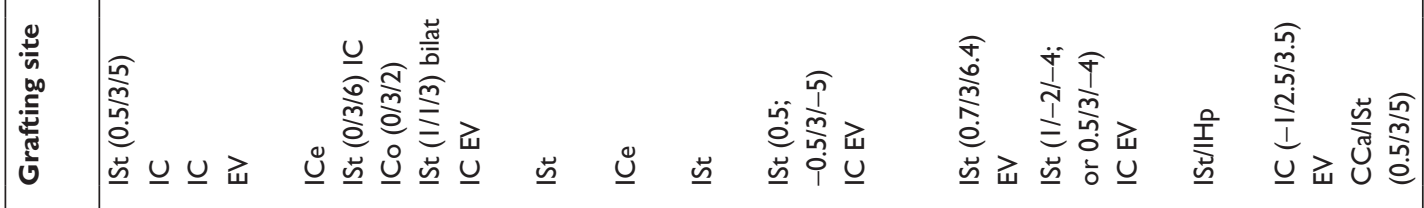

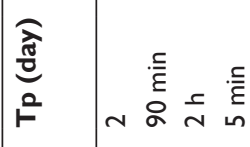

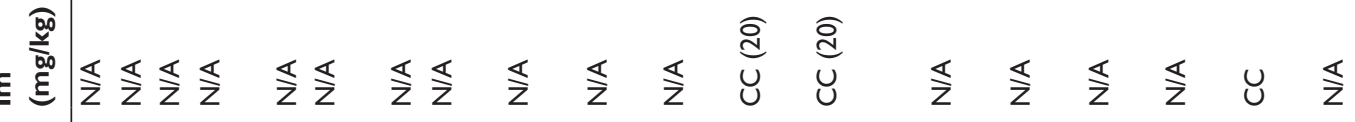

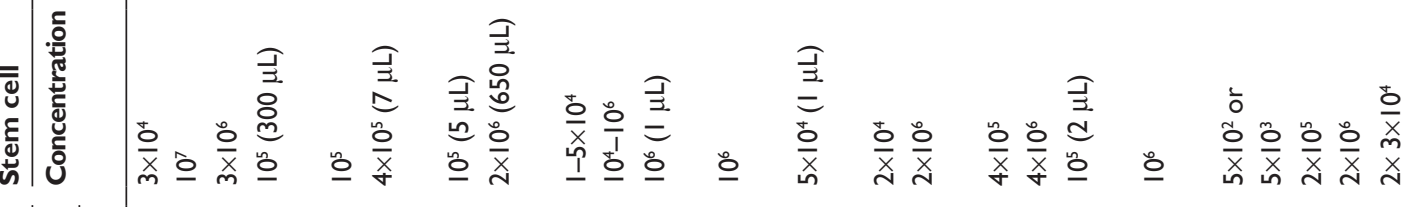

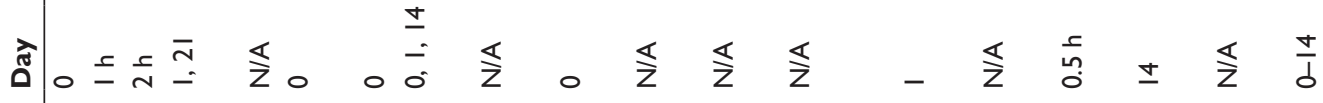

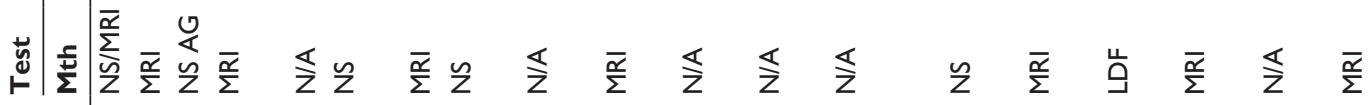

\section{.}

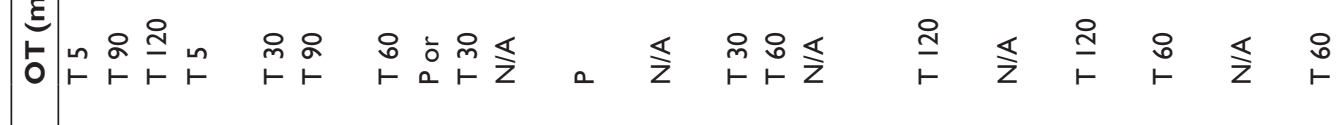

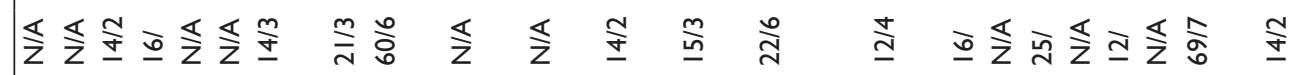

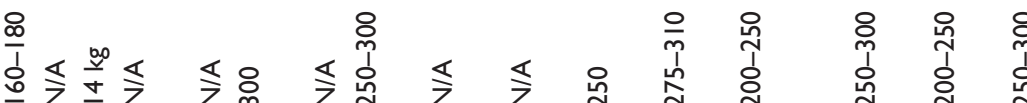

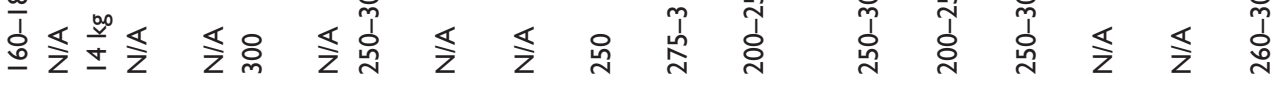
$\begin{array}{llllllllllllll}\frac{\pi}{Z} \bar{Z} \Sigma \Sigma & \frac{\pi}{Z} \Sigma & 4 \Sigma & \Sigma & \bar{Z} & \Sigma & \Sigma & 4 & \Sigma & \Sigma & 4 & \Sigma & \Sigma & \Sigma\end{array}$ 总 $\mathrm{d}$ 


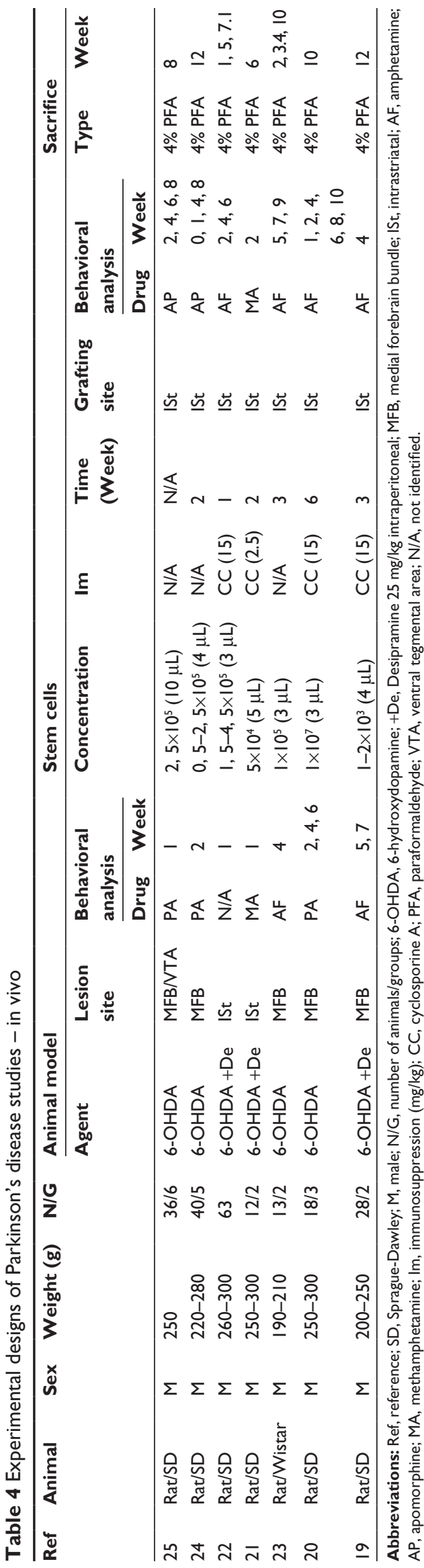

Only one study ${ }^{23}$ reported the method used to determine cell viability (Annexin V/propidium iodide). No studies mentioned the relative value of SPION cell labeling efficiency.

\section{Multiple sclerosis and ALS}

Only five studies ${ }^{30-34}$ (Table 2) were selected that used cells from different sources, such as: stem cells derived from human skeletal muscle - SkmSCs,${ }^{30}$ bone marrow derived human MSC, ${ }^{34}$ amniotic fluid derived from human stem cells, ${ }^{32}$ human embrionary stem cells, ${ }^{33}$ and neural rat stem cells. ${ }^{31}$ To analyze the culture mediums, two studies ${ }^{32,34}$ used basic DMEM, and one study ${ }^{30}$ supplemented the medium with epidermal growth factor (EGF; $20 \mathrm{ng} / \mathrm{mL}$ ), basic fibroblast growth factor (bFGF; $10 \mathrm{ng} / \mathrm{mL}$ ), neural stem cell growth $\mathrm{N} 2$ and Noggin $(100 \mathrm{ng} / \mathrm{mL})$, and Kim et al ${ }^{33}$ used only DMEM supplemented with stem cell N2.

The cell concentration used in these studies ranged from $10^{5}$ to $10^{6}$ cells. All selected studies used commercially available particles: Endorem ${ }^{\mathrm{TM}}$, Feridex ${ }^{\circledR}$, Resovist ${ }^{\circledR}$, Molday ION, and Sinerem ${ }^{\circledR}$, as described in the previous discussion (see Physico-chemical characteristics of SPION section). Only two studies ${ }^{31,32}$ identified SPION concentrations ranging from $35 \mu \mathrm{g} / \mathrm{mL}$ to $1,000 \mu \mathrm{g} / \mathrm{mL}$. Related to the incubation period, one study ${ }^{34}$ used ranged intervals, 24-48 hours for labeling, and two other studies ${ }^{31,32}$ set a time of 72 hours.

For cell viability, one study ${ }^{30}$ used caspase 3 , TUNEL assay method of analysis, and another study ${ }^{32}$ used only MTT assay. Regarding the efficiency of cell labeling, the studies $^{30-32}$ only used the term "good labeling", and two studies $^{31,32}$ reported $100 \%$ efficiency.

In the clinical study selected, ${ }^{34}$ MSC labeled with Feridex $^{\circledR}$ (Advanced Magnetic) injected intrathecally or intravenously led to immediate immunomodulatory effect, and promoted axonal demyelination.

\section{In vivo experiments - human trial or animal models with SPION/SC}

Of the 32 studies selected in this review, only two were clinical trials; ${ }^{34,65}$ the remaining 30 studies used experimental or pre-clinical models. Among those, one study ${ }^{75}$ used a dog, two studies ${ }^{62,72}$ used rabbits, 27 studies used rodents, especially Sprague-Dawley rats, and only five studies ${ }^{30-32,63,73}$ used mice. This profile suggests that the use of SPION labeled stem cells for cell therapy with regards to aging brain diseases is still in the initial phase, see Figure 3. Positive aspects and limitations for this therapy will be analyzed for each in vivo experiment. 


\section{Stroke}

As previously mentioned, 20 studies ${ }^{12-15,62-77}$ addressed the therapeutic use of SPION labeled stem cells in stroke, as described in Table 3. Of these, only one was a clinical trial; ${ }^{65}$ the others were experimental research - also called pre-clinical studies. Among these studies we identified two methods in four different animal models. For the experimental model, one study ${ }^{76}$ used a Beagle dog, two studies ${ }^{62,72}$ used New Zealand rabbits, two other studies ${ }^{63,67}$ used mice, and the remaining studies used rats $(200-310 \mathrm{~g}){ }^{12-15,64,66,68-71,73-75,77}$

Regarding the method, four studies ${ }^{13,14,66,73}$ by the same group of Belgian researchers had used the photothrombosis method, by photosensitizing agents, Rose Bengal (10-20 mg/kg) focusing a beam of light $(540 \mathrm{~nm})$ for 20 minutes. The remaining studies ${ }^{12,15,62-64,67-72,74-77}$ used the occlusion method (temporary or permanent) of the cerebral vascular bed. With respect to these studies, only two studies $^{62,71}$ underwent permanent occlusion, the other studies performed temporary occlusion, ranging from 5 minutes $^{72,76}$ to 120 minutes. ${ }^{69,70}$ The most commonly used vascular bed was the cerebral artery, and the internal carotid artery was also used in New Zealand White rabbits ${ }^{62}$ and in rats; ${ }^{71}$ additionally, the common carotid or femoral artery was also used, ${ }^{72}$ for 30 minutes temporary occlusion.

Only five studies ${ }^{12,70,71,75,76}$ conducted behavioral tests, adapted from clinical neurology scales. The remaining studies evaluated the model effectiveness through various parameters of MRI and magnetic fields, which will be described in the next section.

The procedure of grafting stem cells with SPION (SC/ SPION) was performed using both intracerebral application in specific regions, such as striatum ${ }^{12,63,64,67,68,70,73,74}$ hippocampus ${ }^{67}$ and corpus callosum, ${ }^{74}$ or nonspecific regions, such as intraventricular/cortical, ${ }^{13,15,62,66,75}$ as applied in the peripheral vascular bed ${ }^{6,69-72}$ (femoral artery) or cerebral vascular bed ${ }^{15,69,71}$ (internal carotid artery). The average time between the ischemic event and therapy with $\mathrm{SC} /$ SPION was roughly 3.43 days or 82 hours. However, some studies ${ }^{15,71,72,75}$ underwent implantation immediately after stroke, and another study ${ }^{74}$ performed the therapy 14 days after the ischemic event took place. The most significant data found were the functional recovery after 14 days of SC/SPION implantation described by Gutiérrez-Fernandéz et al's study. ${ }^{71}$

The clinical trial ${ }^{65}$ included was composed of 205 patients aged around 71 years with history of ischemic stroke in the past 3 to 31 days with National Institutes of Health Stroke Scores (NIHSS, 10.4 \pm 6.5 ) and percentage thrombolytic medication use at admission $(6.4 \% \pm 1.2 \%)$. This study used adverse effects as a primary outcome, including death, and as a secondary endpoint they assessed motor and cognitive aspects by NIHSS scores, modified Rankin score, the index of Nottingham Extended Activities of Daily Living, the Barthel index, the Mini-Mental State Examination and the Zung depression scale, before and after 10, and 90 days of the $10^{6}$ granulocyte-colony stimulating factor (G-CSF) cells' administration. No significant change was found in the functional scale. A slight improvement was seen in the NIHSS scores and the modified Rankin score. When performing a meta-analysis together with three other studies on this topic an odds ratio of 1.11 was observed, suggesting a low potential benefit for results presented.

\section{Parkinson's disease}

All studies used experimental models based on rodents (Table 4). Of the seven studies ${ }^{19-25}$ which composed this sample, only one study ${ }^{23}$ used Wistar rats, the other studies used Sprague-Dawley rats. The average weight of the animal was $250 \mathrm{~g}$, and the number of animals per group ranged from 12-63 divided into 2-6 groups.

The included studies had control groups, and they infused and compared the medium (DMEM) with the group that received stem cells. The disease induction model used in almost all these studies was the 6-OHDA. Animals were submitted to the drug dependent rotation test (dopaminergic agonist: apomorphine or amphetamine), which was performed more than 20 full turns per minute, for at least 10 minutes. This behavioral test was performed at different periods of time depending on the article; some studies ${ }^{21,22,24}$ applied the test only once after the neurotoxin 6-OHDA administration, but one study ${ }^{19}$ submitted animals to the test several times for 9 weeks. The average observation time was 4 weeks or 28 days before stem cell infusion. The induction model was neurotoxin locally administrated in the medial forebrain bundle (MFB); two studies ${ }^{21,22}$ used intrastriatal injection of neurotoxin.

The mean time after induction of the disease model for stem cell infusion was 4 weeks or 28 days. All studies infused stem cells in different areas within the striatum region as shown in Table 4. The median number of infused cells was around $10^{5}$ cells $/ 3 \mu$, and the animals' observation time after treatment was on average approximately 6.3 weeks or 42 days. Most of these studies used amphetamine ("primer") to verify dopaminergic imbalance inherent to the process of coordination and central motor adjustment. ${ }^{19,21-23}$ On average, animals were sacrificed after 
42 days and in some studies earlier ${ }^{22,23}$ ( 2 weeks), while other studies ${ }^{19,20,24}$ sacrificed animals within 10 weeks for the analysis of correlation between morphological and functional recovery after cell therapy.

\section{Multiple sclerosis and ALS}

There were five studies on stem cells labeled with SPION used in MS or ALS. There was one clinical article, ${ }^{34}$ and the other four articles ${ }^{30-33}$ (Table 5) used experimental models of genetically modified mice to generate autoimmune encephalomyelitis, called Wobbler (Wr). Animals heterozygous for the gene Wr used in studies were 4 weeks ${ }^{31,32}$ to 10 weeks ${ }^{33}$ old; they underwent implantation of SC/SPION intraventricularly at concentrations ranging from $10^{5}$ in the Bigini et $\mathrm{al}^{31}$ study to $10^{6}$ in two other studies. ${ }^{30,33}$ The Bigini et al ${ }^{13}$ study was the one that only used immunosuppressive therapy (cyclosporine $15 \mathrm{mg} / \mathrm{kg}$ daily) during the 28 days of the experiment. After implantation of SC/SPION, these studies monitored animals by neuroimaging using the MRI technique from SC/SPION implantation and up to 28 days, ${ }^{31}$ and the average time of monitoring was 9 days. Other parameters of neuroimaging studies will be addressed in the next section, Table 5 .

The clinical trial ${ }^{34}$ phase one and two, recruited 15 patients with MS and 19 patients with ALS. The mean age of patients with MS was 35 years; they also had a history of disease for about 10 years. ALS patients' mean age was 53 years and their history of disease was about 34 months. Functional scales, EDSS for MS and ALSFRS for ALS were used for therapeutic monitoring, besides the MRI, which will be discussed in the next section. MS patients received $2.5 \times 10^{6} \mathrm{MSC}$ intrathecally. ALS patients also received $6.0 \times 10^{6} \mathrm{MSC}$ intrathecally. Patients were monitored for MSC immunoregulatory behavior for 4, 24, and 48 hours after implantation. Neuroimaging monitoring occurred at the same periods mentioned above, as well as 1 , 3 , and 6 months after implantation. A significant improvement in clinical conditions for both diseases, more evident in MS, was observed using the functional scales previously
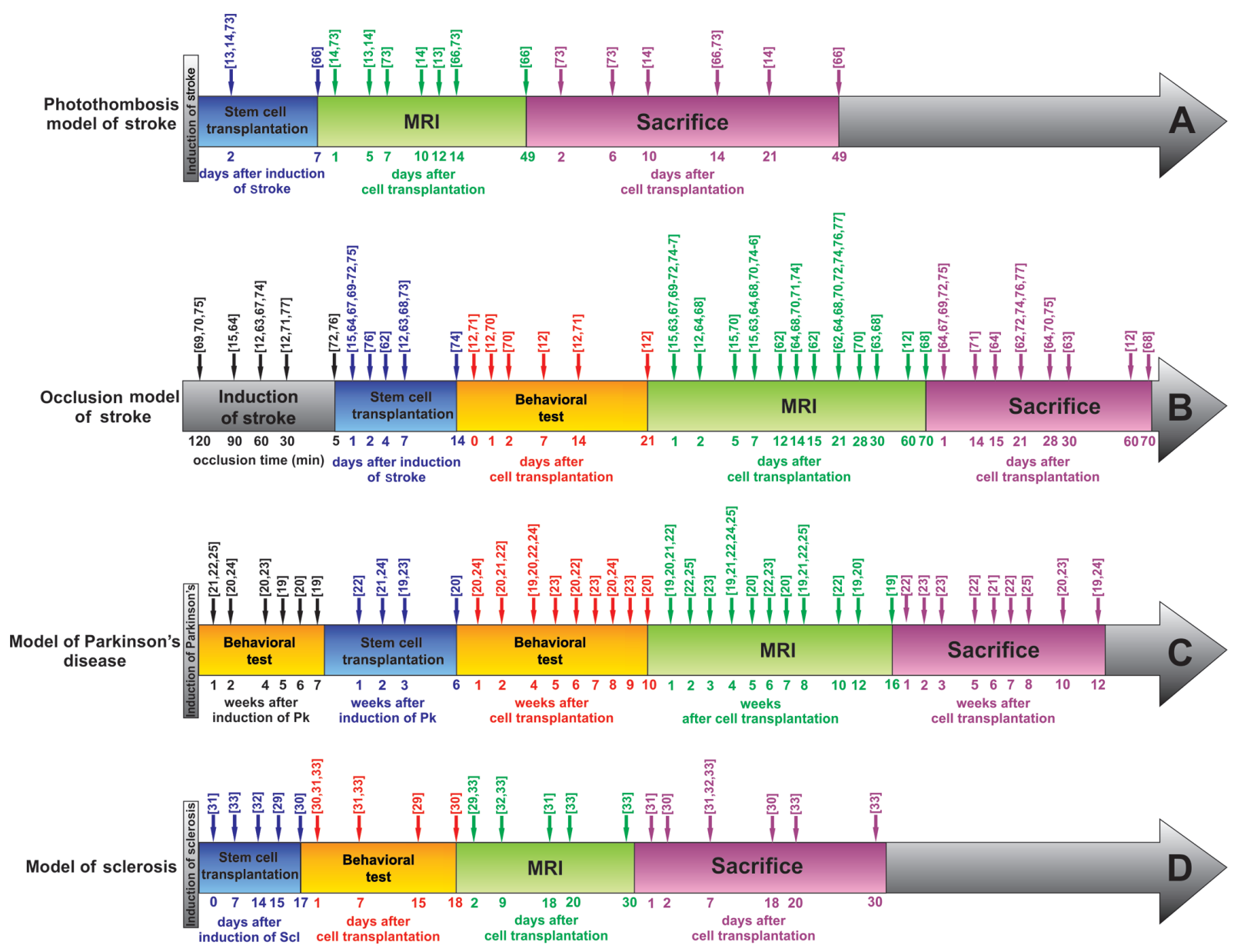

Figure 3 Schematic timeline representation of experimental and sample paradigm.

Notes: (A) Stroke by photothrombosis; (B) stroke by occlusion; (C) Parkinson's disease; and (D) sclerosis.

Abbreviations: Pk, Parkinson's disease; MRI, magnetic resonance imaging; Scl, sclerosis. 
Table 5 Experimental designs of multiple sclerosis or amyothophic lateral sclerosis - in vivo

\begin{tabular}{|c|c|c|c|c|c|c|c|c|c|c|c|c|}
\hline \multirow[t]{3}{*}{ Ref } & \multirow[t]{3}{*}{ Model } & \multirow[t]{3}{*}{ Sex } & \multirow{3}{*}{$\begin{array}{l}\text { Age } \\
(w)\end{array}$} & \multirow[t]{3}{*}{ N/G } & \multicolumn{6}{|l|}{ Stem cells } & \multicolumn{2}{|c|}{ Sacrifice } \\
\hline & & & & & \multirow[t]{2}{*}{ Concentration } & \multirow[t]{2}{*}{$\begin{array}{l}\text { Im } \\
(\mathrm{mg} / \mathrm{kg})\end{array}$} & \multirow[t]{2}{*}{$\begin{array}{l}\text { Time } \\
\text { (day) }\end{array}$} & \multirow[t]{2}{*}{$\begin{array}{l}\text { Infusion site } \\
\text { (AP/ML/DV) }\end{array}$} & \multicolumn{2}{|c|}{$\begin{array}{l}\text { Behavioral } \\
\text { test }\end{array}$} & \multirow[t]{2}{*}{ Type } & \multirow[t]{2}{*}{ Week } \\
\hline & & & & & & & & & Method & Week & & \\
\hline 31 & Mice Wr & $M$ & 4 & $48 / 13$ & $10^{5}$ & CC (I5) & 0 & ICV & MRI & I, 7.1 & $4 \%$ PFA & I, $7 . \mathrm{I}$ \\
\hline 33 & $\begin{array}{l}\text { Mice Wr } \\
(\mathrm{C} 57 \mathrm{BL} / 6)\end{array}$ & $\mathrm{F}$ & $9-10$ & $23 / 2$ & $10^{6}$ & $\mathrm{~N} / \mathrm{A}$ & 7 & $\begin{array}{l}\text { ICV } \\
(0 / I, 0 / 2,5)\end{array}$ & MRI & $\mathrm{I}, 2,3,4$ & $4 \%$ PFA & $2,3,4$ \\
\hline 32 & Mice $\mathrm{Wr}$ & $M / F$ & 4 & $45 / 3$ & $5 \times 10^{5}(5 \mu \mathrm{L})$ & $\mathrm{N} / \mathrm{A}$ & 14 & $\begin{array}{l}\text { ICV } \\
(0,5 / 0,8 / 2,5)\end{array}$ & MRI & 7 & $4 \%$ PFA & 7 \\
\hline 30 & $\begin{array}{l}\text { Mice Wr } \\
\text { (C57BL/6) }\end{array}$ & $\mathrm{F}$ & $6-8$ & $47 / 3$ & $10^{6}$ & N/A & 17 & ICV & MRI & $\begin{array}{l}-1,24-48 \mathrm{~h}, \\
16-18 \mathrm{~d}\end{array}$ & $4 \%$ PFA & $\begin{array}{l}48 \mathrm{~h}, \\
18 \mathrm{~d}\end{array}$ \\
\hline
\end{tabular}

Abbreviations: Ref, reference; Wr, Woldder; F, female; M, male; w, week; N/G, number of animals/groups; Im, immunosuppression; CC, cyclosporine A; ICV, intracerebroventricular; MRI, magnetic resonance imaging; PFA, paraformaldehyde; AP, anteroposterior; ML, mediolateral; DV, dorsoventral; N/A, not identified; h, hours; d, days.

cited. No reports had severe adverse effects (death, disability, etc). An improvement in the immunoregulatory condition within 24 hours after the MSC implantation was also observed.

\section{Imaging techniques to assess the therapy efficacy}

The SC/SPION behavior or scattering in the nervous system as well as their habilitation or functional improvement after implantation can be performed by a technological arsenal. This arsenal varies from technical or histological tests (Berlin blue, Prussian blue, cresyl violet, etc), immunohistological (antibody to tyrosine hydroxylase, glial fibrillary acidic protein, etc), to molecular (real-time polymerase chain reaction [rtPCR]), Bioplex assay to check the immunological status, etc) in ex vivo tissue or post mortem, see Table 6 .

There are tests that can be performed in vivo, such as functional recovery by radioisotopes (PET or SPECT) or complexed fluorophores with substances that mimic the neurochemical of neural systems or networks. Briefly, these articles addressed several neuroimaging techniques (Table 6) using in vivo and ex vivo techniques. All studies used MRI and various magnetic fields from 1.5 tesla $(\mathrm{T})^{13,24,25,70,72}$ to 9.4 T. ${ }^{14,21,33,67,69,73}$ The next paragraphs describe the use of these technologies in each neurodegenerative disease.

\section{Stroke}

MRI equipment was used in all stroke studies to monitor SC/SPION distribution in vivo (Table 6). MRI used magnetic fields that ranged from $1.5 \mathrm{~T}^{13,70,72}$ to $9.4 \mathrm{~T}^{14,67,69,73}$ and the sequence most used was 3D spin echo, weighting T2. The average monitoring period was 13 days, ranging from the day of SC/SPION injection to 70 days $^{68}$ after implantation. The ex-vivo analysis was observed in most studies, and they generally used the immunohistochemistry Prussian
Blue assay to locate SC/SPION after implantation in several brain and/or peripheral regions, as described in the previous section.

In most studies we observed the concomitant presence of iron and stem cells in the ischemic region affected by stroke. ${ }^{12-14,63,66,67,69,71,73,76}$ In addition, the presence or over expression of a series of molecules in the ischemic region was also observed by immunohistochemistry. The most prevalent was the increased expression of GFAP, followed by NeuN, vimentin, and tubulin, suggesting that stem cells' presence can change the ischemic microenvironment and promote structural support reorganization, enabling proliferation of new cells. ${ }^{12,67,68,70,71,73,74,76}$

Imaging methods most frequently used in these studies were flow cytometry ${ }^{12,14,62}$ followed by microscopy, confocal microscopy, ${ }^{71}$ electronic microscopy,${ }^{67}$ electrophysiology of potassium channel, ${ }^{12}$ or microarray/cytogenetic. ${ }^{13,14}$

\section{Parkinson's disease}

All selected studies performed "homing" or cell migration analysis in vivo by MRI. The magnetic field of the equipment ranged from $1.5 \mathrm{~T}^{24,25}$ to $9.4 \mathrm{~T}^{21}$ and most studies used the fast low-angle shot (FLASH) protocol in T2-weighted sequence, in the period ranging from 1 day $^{22,24}$ to 24 weeks, or 168 days $^{23}$ after implantation of SC/SPION.

Two studies ${ }^{23,24}$ reported the presence of hypo signal in the striatum and substantia nigra. ${ }^{23,24}$ All studies that used histological techniques to analyze the SC/SPION therapeutic efficacy ex vivo perfused animals with $4 \%$ paraformaldehyde and conducted an immunohistochemical assay for tyrosine hydroxylase (TH), reporting an increased number of $\mathrm{TH}$ positive neurons. Other studies ${ }^{20,21,25}$ observed an increase in signaling of neural growth factors, and neuroprotective proteins such as GFAP after 6 weeks. ${ }^{21}$ This dopaminergic recovery was also observed in PET, ${ }^{21}$ high-performance 
Table 6 Detection methods of SPION and therapeutic response

\begin{tabular}{|c|c|c|c|c|c|c|}
\hline \multirow{2}{*}{$\begin{array}{l}\text { Neurological } \\
\text { disorder }\end{array}$} & \multirow[t]{2}{*}{ Ref } & \multicolumn{5}{|c|}{ Magnetic resonance imaging } \\
\hline & & MF (T) & Sequence & $\begin{array}{l}\text { Weighted images } \\
\text { (TR/TE; ms) }\end{array}$ & FOV; MT; ST & Time \\
\hline \multirow[t]{22}{*}{ Stroke } & 76 & 3.0 & $\mathrm{~N} / \mathrm{A}$ & $\mathrm{T} 2 *: 2,560 / 6.8$ & $\mathrm{~N} / \mathrm{A} ; \mathrm{N} / \mathrm{A} ; 1.6 \mathrm{~mm}$ & $\mathrm{I}, 7,2 \mathrm{ld}$ \\
\hline & 15 & $\mathrm{~N} / \mathrm{A}$ & 3D GRE 3D spin echo & T2*: $100 / 10$ T2: $2,000 / 60$ & $256 \times 128 ; 50 \times 50 ; \mathrm{I} \mathrm{mm}$ & $\mathrm{I} h, \mathrm{I}, 3,7 \mathrm{~d}$ \\
\hline & 75 & 3.0 & T2 WI DWI & T2*: 5,000/60 & $200 \mathrm{~mm} ; 320 \times 320 ; 2 \mathrm{~mm}$ & I h, I, 7, I4, 2I, $28 \mathrm{~d}$ \\
\hline & 72 & 9.4 & 3D GRE 3D spin echo & T2: 2,000/I05 T2*: 6,000/70 & $70 \times 70 ; 5 \mathrm{I} 2 \times 5 \mathrm{I} 2 ; \mathrm{I} \mathrm{mm}$ & $10 \mathrm{~h}, 21 \mathrm{~d}$ \\
\hline & 65 & 3.0 & 3D spin echo & T2: $16.11 / 3$ & $\mathrm{~N} / \mathrm{A}$ & $10 \mathrm{~d}$ \\
\hline & 63 & 3.0 & spin echo & T2: 5,840/I04 & $45 \times 45 ; 256 \times 256 ; 1.5 \mathrm{~mm}$ & $\mathrm{I}, 3,7,30 \mathrm{~d}$ \\
\hline & 71 & 7.0 & 3D RARE 8 & T2: N/A & N/A & $\mathrm{I}, \mathrm{I} 4 \mathrm{~d}$ \\
\hline & 14 & 9.4 & 2D MSMD 3D FLASH & $\mathrm{T} 2: 6,000 / 10 \mathrm{~T} 2: 100 / 12$ & $40 \times 40 ; 256 \times 256 ; 2 \mathrm{~mm}$ & $12 \mathrm{~h}, 10 \mathrm{~d}$ \\
\hline & 64 & 2.35 & Spin echo & T2: $400 / 25$ & $234 \times 234 ; 0 ; 469 \mathrm{~mm}$ & $0,1,15,28 \mathrm{~d}$ \\
\hline & 62 & 3.0 & Turbo spin echo & T2: $2,548 / 80$ & $80 \times 80 ; 224 \times 205 ; 1.5 \mathrm{~mm}$ & $\mathrm{I}, 8, \mathrm{II}, \mathrm{I7} \mathrm{d}$ \\
\hline & 73 & 9.4 & 3D FLASH 2D multi-echo & T2: 2,250/I0; TI: N/A & $4.0 \times 4.0 ; 256 \times 256 ; 0.4 \mathrm{~mm}$ & $4 \mathrm{~h}, 2,4,7$ and $\mathrm{I} 4 \mathrm{~d}$ \\
\hline & 12 & 7.0 & 3D spin echo & T2: $82.5 / 4,000$ & $5 \times 5 \mathrm{~cm} ; 256 \times 256 ; 0.6 \mathrm{~mm}$ & $2,60 \mathrm{~d}$ \\
\hline & 13 & 1.5 & Turbo spin echo GRE & T2: $2,000 / 8$ I & $5 \mathrm{~cm} ; 5 \mathrm{I} 2 \times 5 \mathrm{I} 2 ; 1.5 \mathrm{~mm}$ & $\mathrm{I}, 5,12 \mathrm{~d}$ \\
\hline & & & & T2*: 280/20 & & \\
\hline & 70 & 1.5 & Turbo spin echo & T2: $5,000 / 90$ & $120 \times 120 ; 256 \times 128 ; 2 \mathrm{~mm}$ & $-I, I, 3,7,|4,2| d$ \\
\hline & 68 & 4.7 & Spin echo; & TI: $600 / 14$ & $4 \times 3 \mathrm{~cm} ; 256 \times 196 ; 1 \mathrm{~mm}$ & $2,7-70 d$ \\
\hline & & & RARE; & $\mathrm{T} 2: 5,000 / 90$ & $4 \times 3 \mathrm{~cm} ; 256 \times 196 ; \mathrm{I} \mathrm{mm}$ & \\
\hline & & & FLASH; & T2*: 758/30 & $4 \times 3 \mathrm{~cm} ; 256 \times 196 ; \mathrm{I} \mathrm{mm}$ & \\
\hline & 69 & 4.7 or 9.4 & $\begin{array}{l}\text { 3D }(\mathrm{T} 2 *) \\
\text { 3D spin echo }\end{array}$ & $\begin{array}{l}\text { T2*: } 560 / 20 \\
\text { T2: } 1,300 / 98\end{array}$ & $\begin{array}{l}4 \times 3 \times 1 \mathrm{~cm} ; 256 \times 96 \times 32 ; \mathrm{N} / \mathrm{A} \\
34 \times 22 \times 1 \mathrm{I} ; 28 \times 64 \times 32 ; \mathrm{N} / \mathrm{A}\end{array}$ & I h, 2 h, I d \\
\hline & 67 & 7.0 or 9.4 & $\begin{array}{l}\text { 3D GRE } \\
\text { Spin-echo multislice }\end{array}$ & $\begin{array}{l}\text { T2*: } 300 / 5 \\
\text { T2: N/A }\end{array}$ & $\begin{array}{l}10 \times 16 \times 4 ; 128 \times 128 \times 12 ; \mathrm{N} / \mathrm{A} \\
3.5 \mathrm{~cm} ; 128 \times 128 ; \mathrm{I} \mathrm{mm}\end{array}$ & $24 \mathrm{~h}, 14 \mathrm{~d}$ \\
\hline & 66 & 4.7 & Turbo spin echo & T2: $2,000 / 42.5$ & $3.5 \mathrm{~cm} ; 256 \times 256 ; 0.5 \mathrm{~mm}$ & $14-49 d$ \\
\hline & 74 & 7.0 & 2D multislice & T2: $200 / 20$ & $20 \times 12 \times 10 ; 256 \times 256 \times 128$ & $6,8,11,16 \mathrm{~d}$ \\
\hline \multirow[t]{7}{*}{ Parkinson's } & 25 & 1.5 & $\begin{array}{l}\text { 3D FLASH } \\
\text { FFE }\end{array}$ & T2: 388/23 & $\begin{array}{l}0.5-0.7 \mathrm{~mm} \\
205 \times 256 ; 120 ; 2 \mathrm{~mm}\end{array}$ & I, 2, 4, $8 \mathrm{w}$ \\
\hline & 24 & 1.5 & FFE & T2: $274 / 12$ & $60 \times 60 ; 256 \times 256 ; 1.2 \mathrm{~mm}$ & $\mathrm{I}, 4,8$ and $12 \mathrm{w}$ \\
\hline & 22 & 7.0 & RARE; 3D & T2: 3,500/75 & $256 \times 256 ; 256 \times 256 ; 0.7 \mathrm{~mm}$ & $\mathrm{I}, 5$ and $7.1 \mathrm{w}$ \\
\hline & 21 & 9.4 & $\begin{array}{l}\text { FLASH } \\
\text { FLASH }\end{array}$ & $\begin{array}{l}\text { T2*: } 150 / 14 \\
\text { T2: } 500 / 40\end{array}$ & $\begin{array}{l}256 \times 256 ; 128 \times 96 \times 24 ; 0.15 \mathrm{~mm} \\
40 \times 40 ; 256 \times 128 ; 0.5 \mathrm{~mm}\end{array}$ & $3,6 w$ \\
\hline & 23 & 7.0 & 2D GRE & T2: $400.4 / 5.4$ & $N / A$ & $2 \mathrm{~d}, 4,8$ \\
\hline & 20 & 1.5 & $\begin{array}{l}\text { Spin-echo fast } \\
\text { spin-eco GRE }\end{array}$ & $\begin{array}{l}\text { TI: } 340 / 11 \text { T2: 3,000/102 } \\
\text { T2*: 200/20 }\end{array}$ & $6 \times 6 \mathrm{~cm} ; 256 \times 256 ; 2 \mathrm{~mm}$ & $\begin{array}{l}16 \text { and } 24 w \\
1,2,4,6, \\
8 \text { and } 10 w\end{array}$ \\
\hline & 19 & 4.7 & FLASH & $\mathrm{T} 2: 3,500 / 40$ & $256 \times 256 ; 0.5 \mathrm{~mm}$ & $4 w$ \\
\hline \multirow[t]{6}{*}{ Sclerosis } & 31 & 3.0 & Spin echo & T2: $4,000 / 36$ & $2 \times 2 ; 256 \times 256 ; \mathrm{I} \mathrm{mm}$ & $\mathrm{I}, 7,28 \mathrm{~d}$ \\
\hline & 33 & 9.4 & 2D FLASH & T2: $316.5 / 3.49$ & I. $6 \times 1.6 ; 256 \times 256 ; 0.4 \mathrm{~mm}$ & $\mathrm{I}, 10,20,30 \mathrm{~d}$ \\
\hline & 32 & 7.0 & RARE8 & T2: $3,300 / 54$ & $2.2 \times 2.2$ & $\mathrm{I}, 18 \mathrm{w}$ \\
\hline & & & FLASH & T2*: $1,000 / 7$ & $256 \times 256$ & \\
\hline & & & Spin echo & TI: 300/II, 7 & $\mathrm{I} \mathrm{mm}$ & \\
\hline & 30 & 3.0 & R2 EPI & T2: 2,500/400 T2: 200/3, 3 & $N / A$ & $N / A$ \\
\hline
\end{tabular}

Abbreviations: SPION, superparamagnetic iron oxide nanoparticle; FLASH, fast low-angle shot; $h$, hours; ST, slice thickness; TR, repetition time; TE, echo time; Ref, reference; d, day; MF, magnetic field; GRE, gradient echo; RARE, rapid acquisition with relaxation enhancement; MSMD, multislice - multiecho; FFE, fast field echo; R2, reciprocal rate; EPI, echo planar; CISS, constructive interference in steady state; FOV, field of view; MT, matrix thickness; AP, Prussian Blue assay; St, count esteriological; Str, striatal region; TH, tyrosine hydroxylase; NiS, Nissl staining or methylene blue; ImH, immunohistochemical reaction; GFAP, glial fibrillary acidic protein; w, week; rtPCR, real-time polymerase chain reaction; DA, dopamine; HVA, homovanillic acid; MCA, marker for monocytes/macrophages and phagocytic microglia; ChAT, motor neuron and neuromuscular junction counting; EDI, anti macrophages/monocytes antibody; HE, hematoxylin eosin; +, increased; -, decreased; =, unchanged; ME, electron microscopy; FC, flow cytometry; EFG, electrophysiology; CG, cytogenetics; Biol, bioluminescence; MiCo, confocal microscopy; CF, fluorescence-activated cell sorting; ICP-AES, flow cytometer; ISt, intrastriatal; STr rig, right striatal nuclei; NSE, neuron specific enolase; Ir, iron; SC, stem cell; BB, Berlin Blue assay; MBP, myelin basic protein antibody; HuNA, immunostaining against human nuclear antigen antibody; N/A, not identified; vit, vimentin; +, increased; DAT, dopamine transported; GFP, green fluorescent protein. 


\begin{tabular}{|c|c|c|c|c|c|}
\hline \multicolumn{3}{|l|}{ Histological image } & \multicolumn{3}{|l|}{ Other methods } \\
\hline Assay & Time & Result & Technique & Time & Result \\
\hline ImH (Sox2; BrdU) & $21 \mathrm{~d}$ & + Sox2/BrdU & $\mathrm{N} / \mathrm{A}$ & $\mathrm{N} / \mathrm{A}$ & $\mathrm{N} / \mathrm{A}$ \\
\hline HE; BB & $21 d$ & $+\mathrm{BB}$ & $\mathrm{N} / \mathrm{A}$ & N/A & $\mathrm{N} / \mathrm{A}$ \\
\hline AP; HE & $\mathrm{I}, 28 \mathrm{~d}$ & $+\mathrm{AP}$ & N/A & $\mathrm{N} / \mathrm{A}$ & $\mathrm{N} / \mathrm{A}$ \\
\hline HE; ImH (CD3I) & $\mathrm{I}, 2 \mathrm{Id}$ & $+\mathrm{CD} 31$ & $N / A$ & $N / A$ & $N / A$ \\
\hline N/A & $\mathrm{N} / \mathrm{A}$ & N/A & $\mathrm{N} / \mathrm{A}$ & N/A & $\mathrm{N} / \mathrm{A}$ \\
\hline AP; ImH ( $\beta$ tubulin III) & $30 \mathrm{~d}$ & $+\mathrm{AP}, \beta$ tubulin III & $\mathrm{N} / \mathrm{A}$ & N/A & $\mathrm{N} / \mathrm{A}$ \\
\hline AP; ImH (GFAP; VEGF; & $14 \mathrm{~d}$ & =AP; +GFAP; & MiCo & $14 \mathrm{~d}$ & $\mathrm{~N} / \mathrm{A}$ \\
\hline CD90, CDIIC, neurofilament) & & VEGF; CD90 & & & \\
\hline AP; HE; ImH (GFP) & $10,21 \mathrm{~d}$ & +AP; GFP & CF; CG: ME & $10,21 \mathrm{~d}$ & $+\operatorname{Ir} / S C$ \\
\hline ImH MABI28I; & $\mathrm{I}, 15,28 \mathrm{~d}$ & $+M A B \mid 28 I$ & $\mathrm{~N} / \mathrm{A}$ & N/A & $\mathrm{N} / \mathrm{A}$ \\
\hline AP & $21 d$ & $+\mathrm{AP}$ & CF; ICP-AES & $21 \mathrm{~d}$ & $\mathrm{~N} / \mathrm{A}$ \\
\hline AP; ImH GFP; ferritin & $2,6,14 \mathrm{~d}$ & + AP; GFAP & N/A & $\mathrm{N} / \mathrm{A}$ & $\mathrm{N} / \mathrm{A}$ \\
\hline AP; ImH (CDI33; vimentin; & $60 d$ & +AP; GFAP; & EFG; CF; FC; Biol & $2-60 d$ & $\mathrm{~N} / \mathrm{A}$ \\
\hline GFAP; NeuN; synaptophysin) St & & NeuN; CDI33 & & & \\
\hline AP; HE; ImH (EDI; vimentin) & $\mathrm{I}, 5,12 \mathrm{~d}$ & +AP; =EDI; +vit (5 d) & Microarray & 0 & +28 genes \\
\hline $\begin{array}{l}\text { AP; NiS; ImH (BrdU, } \\
\text { NeuN, GFAP, MHC-III) }\end{array}$ & I ISt 28 IV & N/A & $\mathrm{N} / \mathrm{A}$ & N/A & $\mathrm{N} / \mathrm{A}$ \\
\hline $\begin{array}{l}\text { AP; ImH (nestin; } \beta \text { tubulin; } \\
\text { MAP2; TH; GFAP) }\end{array}$ & $\mathrm{N} / \mathrm{A}$ & N/A & N/A & N/A & $\mathrm{N} / \mathrm{A}$ \\
\hline AP; HE & N/A & $+\mathrm{AP}$ & N/A & N/A & N/A \\
\hline AP; NiS; ImH (GFP) & $14 \mathrm{~d}$ & +AP; GFP & $\mathrm{N} / \mathrm{A}$ & $\mathrm{N} / \mathrm{A}$ & $\mathrm{N} / \mathrm{A}$ \\
\hline $\begin{array}{l}\text { AP ImH (CD90, fibronectin, } \\
\text { CD } 45, \text { CDIIb) }\end{array}$ & $14,49 d$ & +AP; CD90, CD45 & ME & $14 \mathrm{~d}$ & $+\operatorname{lr} / S C$ \\
\hline ImH (GFP) & $6,8,11 \mathrm{~d}$ & + GFP & N/A & N/A & $\mathrm{N} / \mathrm{A}$ \\
\hline $\begin{array}{l}\text { ImH (TH; nestin; B-III-tubulin; } \\
\text { GFP); AP }(10 \mu \mathrm{m})\end{array}$ & $8 w$ & +GFP/T H STr rig & PCR (GDNF; TH) & $8 w$ & $+\mathrm{GDN} F / \mathrm{TH}$ \\
\hline $\operatorname{BrdU;}$ AP $(5 \mu \mathrm{m})$ & $12 \mathrm{w}$ & +BrdU STr rig & rtPCR (GFAP; & $12 \mathrm{w}$ & $\S$ \\
\hline $\operatorname{ImH}(\mathrm{TH}) ; \mathrm{AP}(40 \mu \mathrm{m}) \mathrm{St}$ & $7.1 \mathrm{w}$ & $+\mathrm{TH}+\mathrm{STr}$ rig & $\begin{array}{l}\text { nestin; NSE; TH) } \\
\text { HPLC (Cl8) brain }\end{array}$ & I w & $>2.5 \times$ \\
\hline ImH (GFAP; TH); AP (10 $\mu \mathrm{m})$ & $6 w$ & $=\mathrm{TH}+\mathrm{STr}$ & $\begin{array}{l}\text { (DA; HVA) } \\
\text { PET ("C-raclopride; }\end{array}$ & $2,4 w$ & $* *$ \\
\hline ImH (SSEA-I; TH; DAT; & $8,16,24 w$ & $+10 \%$ GFP + with AP & $\begin{array}{l}560 \mathrm{MBq}) \\
\text { N/A }\end{array}$ & N/A & $\mathrm{N} / \mathrm{A}$ \\
\hline $\begin{array}{l}\text { 5-HT; GFP); AP }(20 \mu \mathrm{m}) \mathrm{St} \\
\text { AP; ImH (nestin; GFAP; } \\
\beta \text {-tubulin; IgG-FITC; } 40 \mu \mathrm{m})\end{array}$ & $10 w$ & +GFP with AP & N/A & N/A & $\mathrm{N} / \mathrm{A}$ \\
\hline $\operatorname{ImH}(\mathrm{TH} ; 30 \mu \mathrm{m})$ & $14-16 w$ & $+\mathrm{II} \% \mathrm{TH}+\mathrm{ST}$ right & $\begin{array}{l}\text { PET ("'C-CFT; } \\
10 \mathrm{mCi})\end{array}$ & $4 w$ & + DAT \\
\hline ImH (curboxy dextran; HLA-I) & $28 \mathrm{~d}$ & +carboxy dextran; HLA-I & $\mathrm{N} / \mathrm{A}$ & N/A & $\mathrm{N} / \mathrm{A}$ \\
\hline $\begin{array}{l}\text { AP; ImH (HuNA; B-III-tubulin; } \\
\text { GFAP; OCT-4; MBP) }\end{array}$ & $5,15,25,45 \mathrm{~d}$ & $\begin{array}{l}+ \text { HuNA/B-III- } \\
\text { tubulin/MBP }\end{array}$ & N/A & N/A & $\mathrm{N} / \mathrm{A}$ \\
\hline $\begin{array}{l}\text { ImH (GFAP), } \\
\text { CDIIb) }\end{array}$ & $9,18 \mathrm{w}$ & $\begin{array}{l}\text { GFAP, } \\
\text { CDIIb }\end{array}$ & $\begin{array}{l}\text { ChAT; } \\
\text { Bioplex; } \\
\text { rtPCR }\end{array}$ & $\begin{array}{l}7,9 \\
18 \mathrm{w}\end{array}$ & $\mathrm{N} / \mathrm{A}$ \\
\hline AP & $\mathrm{N} / \mathrm{A}$ & $+\mathrm{AP}$ & ME & N/A & $\mathrm{N} / \mathrm{A}$ \\
\hline
\end{tabular}


liquid chromatography (HPLC), ${ }^{22}$ and more recently in rtPCR $^{24,25}$ (Table 4).

\section{Multiple sclerosis and ALS}

All studies used MRI technique to monitor SC/SPION distribution through the brain after intrathecal ${ }^{34}$ or intracerebroventricular $^{30-33}$ cell application (Table 5). The magnetic fields ranged from $1.5 \mathrm{~T}^{34}$ to $9.4 \mathrm{~T},{ }^{33}$ the spin echo sequence ${ }^{31,32}$ was more frequent, and the mean monitoring period was 32 days, ranging from 24 hours after implantation ${ }^{30,31,34}$ to 18 weeks. ${ }^{32}$ One study ${ }^{30}$ used Prussian Blue for ex vivo analysis, the other studies used immunohistochemistry assays for class I - human leucocyte antigens ${ }^{31}$ and GFAP. ${ }^{32,33}$ All these markers were enhanced in the regions of motor tracts of the brain after 7 days of SC/SPION administration. Two studies $^{32,34}$ used Bioplex equipment to check the immunephenotypic condition, and they also observed a significant improvement even after the period previously reported. In a clinical trial conducted by Karussis et al, ${ }^{34}$ the immunophenotypic improved not accompanied by the clinical improvement or increase functional neuromuscular junction. Regarding the modulation process of structural and physiological events of neuromuscular junctions, studies by Politi et $\mathrm{a}^{30}$ and Canzi et $\mathrm{al}^{32}$ observed an increase in the reorganization of neuromuscular myofibrils by electron and optical microscopy after 48 hours of SC/MSC administration.

\section{Discussion}

The brain aging process is characterized by a reduced cortical area, and reduction in the number of neurons and their connections. ${ }^{78}$ This process is multifactorial and the individual's lifestyle is considered to be a high impact factor in the aging process. ${ }^{79,80}$ Obesity, stress, and depression accelerate this process. ${ }^{80} \mathrm{~A}$ nutritional diet with polyphenolic compounds, curcumin or glucose restriction, physical activity, and mentally stimulating pursuits are considered beneficial factors. ${ }^{81}$ Genetics, in addition to lifestyle also play central roles in this process. ${ }^{82}$ There are several studies suggesting an increased expression in miRNA network that modulates the inflammatory profile of neural and glial cells, also affecting behavioral aspects and, therefore, influences the epigenetics, ${ }^{79,83}$ or the cells' telomerase activity by accelerating or slowing down the process of cerebral aging. ${ }^{84}$

In this sense, accelerated brain aging by environmental components, behavioral or genetic, makes the brain structure vulnerable to two distinct disease processes, which are associated in some situations: i) oxidative stress modulating the chronic accumulation of protein clusters ( $\alpha$-synuclein, $\beta$ amyloid, Tau, etc) or intracellular apoptotic/degenerative events by the increased immune response, and ii) the ischemic event, acute in most situations, caused by trauma or thromboembolic events. ${ }^{48} \mathrm{AD}$, Parkinson's disease, stroke, and sclerosis are the most prevalent diseases related to the cerebral aging process. ${ }^{54}$

Cell therapy is a nonpharmacological option to treat the mentioned diseases. ${ }^{48}$ This technique sometimes restores neural population through a process of cell transdiffere ntiation, ${ }^{51,85}$ growth factor releasing and/or modulating the inflammatory microenvironment, ${ }^{54,86}$ and is therefore emerging as a therapeutic option in diseases refractory to other treatments. The MSC are multipotent, ${ }^{87}$ and besides providing the beneficial aspects described above, they have greater safety regarding teratogenicity; ${ }^{88,89}$ however, these cells can migrate randomly, mainly to inflammatory or apoptotic sites. ${ }^{87}$

For this reason, the goal of this review was to systematically analyze scientific data of pre-clinical and clinical trials to provide an overview of the use of SPION labeled stem cells for diseases related to the aging brain process, such as ischemic stroke, Parkinson's disease, sclerosis, and dementia/AD.

The use of SPION labeled stem cells for cell therapy for diseases related to cerebral aging is not new. The first study $^{90}$ on this subject dates back to 1988 . The majority of studies analyzed in this review used commercial compounds, especially Feridex ${ }^{\circledR}\left(\right.$ Endoren $\left.^{\circledR}\right)$ adopted by 18 studies of the 32 included (57\%), and 24 of 32 included (75\%) studies adopted dextran coated compounds. Although literature abounds with studies on the use of SPION for labeling MSC, this technique was questioned by Guenoun et $\mathrm{a}^{91}$ after this author established that paramagnetic gadolinium contrast enabled a better internalization efficiency and higher cell viability by the use of trypan blue. However, Jasmin et $\mathrm{a}^{92}$ remarked that induction of reactive oxygen species by this contrast can affect the cells' proliferative potential. In our review, the main transfection agent identified in 12 of $32(38 \%)$ selected articles was PLL. Studies ${ }^{93,94}$ suggest that PLL use facilitates the SPION internalization process by MSC in MRI analysis, decreasing the toxicity related to SPION concentration, to the period of stem cell and SPION incubation.

DMEM was the main culture medium used (26 of 32 [86\%]), and all aforementioned studies also used DMEM for SPION or gadolinium internalization with stem cells. Accordingly, the SPION and stem cells' incubation period ranged from 1 to 72 hours, and most (12 of 32 [32\%]) studies used 24 hours. The Jasmin et a $1^{92}$ findings corroborate this 
fact by showing that SPION MRI is significantly improved after 24 hours, ${ }^{92}$ and that cell viability is reduced after 30 hours. This same finding was observed in the Mamani et al study. ${ }^{93}$ Only two publications used multimodal nanoparticles ${ }^{14,72}$ for stem cell labeling, and one of them used the complexation technique with fluorgold. Another study used a commercial compound named FluidMag. The use of multi- or polymodal particles is new in the study of stem cell therapy functionality. ${ }^{92}$

The most commonly used stem cells in the selected articles were MSC (65\%), followed by embryonic stem (15\%), neural stem cell (12\%), hematopoietic stem cell (4\%), and stem cells from amniotic fluid (4\%). The same distribution of the stem cells used was also observed in a review published in Cell Transplantation, between 2008 and 2009. ${ }^{95}$ The origins or sources of stem cells used in publications were human (118 of 214 [55\%]), followed by mouse (49 of 214 [18\%]). These results corroborate our analysis that identified eleven studies (42\%) using human stem cells and eight studies (38\%) using rat cells. In this sense, most studies used heterologous cells, since $98 \%$ of studies used rodents. In addition, we also observed the use of immunosuppressive drugs such as cyclosporine, in ten of eleven studies of heterologous therapy.

The SPION labeled stem cell therapy detected more evident in upper magnetic fields, but in all MRI fields identified (1.5 to $11 \mathrm{~T}$ ) and protocols (Table 6), the $\mathrm{SC} /$ SPION were location in the therapeutic target, penumbra region for stroke, nigrostriatal region for Parkinson's disease, and regions of the internal capsule and corticospinal tract for ALS. This result was also evidenced by our group and by other articles. ${ }^{48,88,89,95}$ The functional improvement was identified by an extensive variation in the method of measurement among selected groups of diseases (stroke, Parkinson's disease, sclerosis).

Among the 20 selected studies on stroke, only one studied ${ }^{65}$ the effects of stem cell therapy in patients up to 30 days after the ischemic event, and found that therapy efficacy was low in several functional outcomes analyzed (cognition, motor skills, socio-familial, etc). Recent experimental studies showed that MSC are more efficient at modulating the neural microenvironment by promoting growth factor release and glial activation, mainly of oligodendrocytes, which enables better structural and functional reorganization compared with hematopoietic stem cells used in this study. ${ }^{96,97}$

This observation is supported by articles included in this review, which, besides confirming the ischemic region reduction after 7 days after stem cells' administration in both photothrombosis and temporary occlusion of the middle cerebral artery model, also showed an improvement in memory behavioral tests, such as the Morris water maze, and adapted neurological scales.

For the stroke model most of the articles (13 of 32 [65\%]) used the middle cerebral artery occlusion, and others conducted a temporary occlusion of 1 hour on average. Two studies underwent permanent occlusion as control injury. Some reviews in the literature highlight the model by temporary occlusion of the middle cerebral artery as the most widely used model, because there is the advantage in not performing a craniotomy, and restriction of the affected area overcomes the disadvantage of the injury not being generated by a thromboembolic event. ${ }^{98,99}$ The use of molecular biology techniques has increased (PCR, Western blot, ELISA, etc). In articles selected for this review the functional genomics in experimental studies of stroke was observed in microarray ${ }^{12,13}$ and cytogenetics. ${ }^{14}$

The model for Parkinson's disease induction was neurotoxin 6-OHDA injected at the MFB. The articles reported functional improvement using the apomorphine rotation test, on average, after 3 weeks. It was also observed that animals undergoing cyclosporine therapy before receiving stem cells in the striatal region, had functionally recovered after 7.3 weeks. This result was demonstrated through rotational test using methamphetamine and neuroimaging exams. MRI presented magnetic fields ranging from 1.5 to $9.4 \mathrm{~T}$, and the protocol FLASH parameter-weighting T2 was the most frequent.

In general, after 11.3 weeks animals were sacrificed and perfused with 4\% paraformaldehyde. The animals' brains were removed and mainly the CPU/striatum and substantia nigra were examined by immunohistochemical assay, and found increased tyrosine hydroxylase and $\mathrm{TH}$ positive neurons. This dopaminergic recovery was also observed by other methods, such as PET (Bjorklund et $\mathrm{al}^{19}$; Jackson et $\mathrm{al}^{21}$ ), HPLC, ${ }^{22}$ and more recently by rtPCR. ${ }^{15,24}$

The articles that evaluate the use of SPION labeled stem cells in MS identified that the SPION internalization process did not modify the stem cells' viability, proliferation, metabolism, and phenotype. ${ }^{32}$ Furthermore, it seems a good therapy for ALS, ${ }^{29,31,32}$ since the motor skills significantly improve in behavioral tests and electrophysiology about 7 days after stem cells' implantation. Therefore, there is extensive literature on cell therapy benefits for ALS, ${ }^{100} \mathrm{MS},{ }^{101}$ sclerosis, and other demyelinating diseases.

According to the presented data, nanobiotechnology constitutes a powerful tool to study stem cells' use to treat 
diseases related to the aging brain, particularly for allowing tracking of these cells in vivo. Due to the central nervous system complexity, cell-based therapy is a challenge, and nanomedicine tools for monitoring and guiding these studies are highly desirable.

\section{Acknowledgments}

This work was supported by Instituto Israelita de Ensino e Pesquisa Albert Einstein (IIEP), CNPq, FINEP/CAPES, NAPNA, INEC and FAPESP. We thank Edna Terezinha Rother for her support in the construction of the search strategies.

\section{Disclosure}

The authors report no conflicts of interest in this work.

\section{References}

1. Mora F, Segovia G, del Arco A. Aging, plasticity and environmental enrichment: structural changes and neurotransmitter dynamics in several are as of the brain. Brain Res Rev. 2007;55(1):78-88.

2. Terry RD, Katzman R. Life span and synapses: will there be a primary senile dementia? Neurobiol Aging. 2001;22(3):347-348.

3. Quan SA, Jeong JY, Kim DH. The relationship between height and cognitive function among community-dwelling elderly: Hallym aging study. Epidemiol Health. 2013;35:e2013002.

4. Kirkwood TB. A systematic look at an old problem. Nature. 2008; 451(7179):644-647.

5. Mattson MP, Magnus T. Aging and neuronal vulnerability. Nat Rev Neurosci. 2006;7(4):278-294

6. Van Praag H, Kempermann G, Gage FH. Neural consequences of environmental enrichment. Nat Rev Neurosci. 2000;1(3):191-198.

7. Murray CJ, López AD. Mortality by cause for eight regions of the world: global burden of disease study. Lancet. 1997;349(9061):1269-1276.

8. Lindvall O, Kokaia Z. Stem cells in human neurodegenerative disorders-time for clinical translation? J Clin Invest. 2010;120(1): 29-40.

9. Luo Y. Cell-based therapy for stroke. J Neural Transm. 2011;118(1): 61-74.

10. Smith HK, Gavins FN. The potential of stem cell therapy for stroke: is PISCES the sign? FASEB J. 2012;26(6):2239-2252.

11. Donnan GA, Fisher M, Macleod M, Davism SM. Stroke. Lancet. 2008;371(9624):1612-1623.

12. Daadi MM, Li Z, Arac A, et al. Molecular and magnetic resonance imaging of human embryonic stem cell-derived neural stem cell grafts in ischemic rat brain. Mol Ther. 2009;17(7):1282-1291.

13. Lee ES, Chan J, Shuter B, et al. Microgel iron oxide nanoparticles for tracking human fetal mesenchymal stem cells through magnetic resonance imaging. Stem Cells. 2009;27(8):1921-1931.

14. Crabbe A, Vandeputte C, Dresselaers T, et al. Effects of MRI contrast agents on the stem cell phenotype. Cell Transplant. 2010;19(8):919-936.

15. Kamiya N, Ueda M, Igarashi H, Nishiyama Y, Suda S, Okubo S, Katayama Y. In vivo monitoring of arterially transplanted bone marrow mononuclear cells in a rat transient focal brain ischemia model using magnetic resonance imaging. Neurol Res. 2013;35(6):573-579.

16. Rascol O. The pharmacological therapeutic management of levodopainduced dyskinesias in patients with Parkinson's disease. J Neurol. 2000;247(Suppl 2):II51-II57.

17. Van Gerpen JA, Kumar N, Bower JH, Weigand S, Ahlskog JE. Levodopa-associated dyskinesia risk among Parkinson disease patients in Olmsted County, Minnesota, 1976-1990. Arch Neurol. 2006;63(2): 205-209.
18. Dunnett SB, Kendall AL, Watts C, Torres EM. Neuronal cell transplantation for Parkinson's and Huntington's diseases. Br Med Bull. 1997;53(4):757-776.

19. Bjorklund LM, Sánchez-Pernaute R, Chung S, et al. Embryonic stem cells develop into functional dopaminergic neurons after transplantation in a Parkinson rat model. Proc Natl Acad Sci U S A. 2002;99(4): 2344-2349.

20. Yang L, Xia Y, Zhao H, Zhao J, Zhu X. Magnetic resonance imaging of transplanted neural stem cells in Parkinson disease rats. J Huazhong Univ Sci Technolog Med Sci. 2006;26(4):489-492.

21. Jackson J, Chapon C, Jones W, Hirani E, Qassim A, Bhakoo K. In vivo multimodal imaging of stem cell transplantation in a rodent model of Parkinson's disease. J Neurosci Methods. 2009;183(2):141-148.

22. Sadan O, Bahat-Stromza M, Barhum Y, et al. Protective effects of neurotrophic factor-secreting cells in a 6-OHDA rat model of Parkinson disease. Stem Cells Dev. 2009;18(8):1179-1190.

23. Stroh A, Boltze J, Sieland K, et al. Impact of magnetic labeling on human and mouse stem cells and their long-term magnetic resonance tracking in a rat model of Parkinson disease. Mol Imaging. 2009;8(3): 166-178.

24. Guo J, Shen JK, Wang L, et al. In vivo evaluation of cerebral transplantation of resovist-labeled bone marrow stromal cells in Parkinson's disease rats using magnetic resonance imaging. Appl Biochem Biotechnol. 2011;163(5):636-648.

25. Deng X, Liang Y, Lu H, et al. Co-Transplantation of GDNFOverexpressing Neural Stem Cells and Fetal Dopaminergic Neurons Mitigates Motor Symptoms in a Rat Model of Parkinson's Disease. PLoS One. 2013;8(12):e80880.

26. Compston A, Coles A. Multiple sclerosis. Lancet. 2008;372(9648): $1502-1517$

27. Lublin FD, Reingold SC. Defining the clinical course of multiple sclerosis: results of an international survey. National Multiple Sclerosis Society (USA) Advisory Committee on Clinical Trials of New Agents in Multiple Sclerosis. Neurology. 1996;46(4):907-911.

28. Sabatelli M, Madia F, Conte A, et al. Natural history of young-adult amyotrophic lateral sclerosis. Neurology. 2008;71(12):876-881.

29. Linker RA, Mohr A, Cepek L, Gold R, Prange H. Core hypothermia in multiple sclerosis: case report with magnetic resonance imaging localization of a thalamic lesion. Mult Scler. 2006;12(1):112-115.

30. Politi LS, Bacigaluppi M, Brambilla E, et al. Magnetic-resonance-based tracking and quantification of intravenously injected neural stem cell accumulation in the brains of mice with experimental multiple sclerosis. Stem Cells. 2007;25(10):2583-2592.

31. Bigini P, Diana V, Barbera S, et al. Longitudinal tracking of human fetal cells labeled with super paramagnetic iron oxide nanoparticles in the brain of mice with motor neuron disease. PLoS One. 2012;7(2):e32326.

32. Canzi L, Castellaneta V, Navone S, et al. Human skeletal muscle stem cell antiinflammatory activity ameliorates clinical outcome in amyotrophic lateral sclerosis models. Mol Med. 2012;18(3):401-411.

33. Kim H, Walczak P, Kerr C, et al. Immunomodulation by Transplanted Human Embryonic Stem Cell-Derived Oligodendroglial Progenitors in Experimental Autoimmune Encephalomyelitis. Stem Cells. 2012;30(12):2820-2829.

34. Karussis D, Karageorgiou C, Vaknin-Dembinsky A, et al. Safety and immunological effects of mesenchymal stem cell transplantation in patients with multiple sclerosis and amyotrophic lateral sclerosis. Arch Neurol. 2010;67(10):1187-1194.

35. Holzer S, Warner JP, Lliffe S. Diagnosis and management of the patient with suspected dementia in primary care. Drugs Aging. 2013;30(9): 667-676.

36. Horvath J, Herrmann FR, Burkhard PR, Bouras C, Kövari E. Neuropathology of dementia in a large cohort of patients with Parkinson's disease. Parkinsonism Relat Disord. 2013;19(10):864-868.

37. Fletcher LC, Burke KE, Caine PL, et al. Diagnosing Alzheimer's disease: are we any nearer to useful biomarker-based, non-invasive tests? GMS Health Technol Assess. 2013;9:1-7. 
38. Blennow K, de Leon MJ, Zetterberg H. Alzheimer's disease. Lancet 2006;368(9533):387-403.

39. Cummings JL. Treatment of Alzheimer's disease: current and future therapeutic approaches. Rev Neurol Dis. 2004;1(2):60-69.

40. Selkoe DJ. Alzheimer's disease results from the cerebral accumulation and cytotoxicity of amyloid beta-protein. J Alzheimers Dis. 2001;3(1):75-80.

41. Goedert M, Crowther RA. Amyloid plaques, neurofibrillary tangles and their relevance for the study of Alzheimer's disease. Neurobiol Aging. 1989;10(5):405-406.

42. Wevers A, Schröder H. Nicotinic acetylcholine receptors in Alzheimer's disease. J Alzheimers Dis. 1999;1(4-5):207-219.

43. Weissman IL. Stem cells: units of development, units of regeneration, and units in evolution. Cell. 2000;100(1):157-168.

44. Rando TA. Stem cells, ageing and the quest for immortality. Nature. 2006;441(7097):1080-1086.

45. Rossi DJ, Jamieson CH, Weissman IL. Stem cells and the pathways to aging and cancer. Cell. 2008;132(4):681-696.

46. Fuchs E. The tortoise and the hair: slow-cycling cells in the stem cell race. Cell. 2009;137(5):811-819.

47. Artegiani B, Calegari F. Age-related cognitive decline: can neural stem cells help us? Aging (Albany NY). 2012;4(3):176-186.

48. Sanberg PR, Eve DJ, Cruz LE, Borlongan CV. Neurological disorders and the potential role for stem cells as a therapy. Br Med Bull. 2012;101: 163-181.

49. Balaban RS, Nemoto S, Finkel T. Mitochondria, oxidants, and aging. Cell. 2005;120(4):483-495.

50. Kirkwood TB. Understanding the odd science of aging. Cell. 2005; 120(4):437-447.

51. Hess DC, Borlongan CV. Stem cells and neurological diseases. Cell Prolif. 2008;41(Suppl 1):94-114.

52. Hoeijmakers JH. DNA damage, aging, and cancer. $N$ Engl J Med. 2009;361(15):1475-1485.

53. Haigis MC, Yankner BA. The aging stress response. Mol Cell. 2010;40(2):333-344.

54. Duncan GW. The aging brain and neurodegenerative diseases. Clin Geriatr Med. 2011;27(4):629-644.

55. Liu L, Rando TA. Manifestations and mechanisms of stem cell aging. J Cell Biol. 2011;193(2):257-266.

56. Janowski M, Bulte JW, Walczak P. Personalized nanomedicine advancements for stem cell tracking. Adv Drug Deliv Rev. 2012;64(13): 1488-1507.

57. Cromer Berman SM, Walczak P, Bulte JW. Tracking stem cells using magnetic nanoparticles. Wiley Interdiscip Rev Nanomed Nanobiotechnol. 2011;3(4):343-355.

58. Anderson VC, Litvack ZN, Kaye JA. Magnetic resonance approaches to brain aging and Alzheimer disease-associated neuropathology. Top Magn Reson Imaging. 2005;16(6):439-452.

59. Iwanami A, Kaneko S, Nakamura M, et al. Transplantation of human neural stem cells for spinal cord injury in primates. $J$ Neurosci Res. 2005;80(2):182-190.

60. Conner SD, Schmid SL. Regulated portals of entry into the cell. Nature. 2003;422(6927):37-44.

61. Wei JJ, Wang RZ, Lu JJ, et al. [In vivo tracking of bone marrow mesenchymal stem cells labeled with superparamagnetic iron oxide after cerebral ischemia in rats by magnetic resonance imaging]. Zhongguo Yi Xue Ke Xue Yuan Xue Bao. 2007;29(1):73-77. Chinese.

62. Reddy AM, Kwak BK, Shim HJ, et al. In vivo tracking of mesenchymal stem cells labeled with a novel chitosan-coated superparamagnetic iron oxide nanoparticles using 3.0T MRI. J Korean Med Sci. 2010;25(2):211-219.

63. Wang Y, Xu F, Zhang C, et al. High MR sensitive fluorescent magnetite nanocluster for stem cell tracking in ischemic mouse brain. Nanomedicine. 2011;7(6):1009-1019.

64. Detante O, Valable S, de Fraipont F, et al. Magnetic resonance imaging and fluorescence labeling of clinical-grade mesenchymal stem cells without impacting their phenotype: study in a rat model of stroke. Stem Cells Transl Med. 2012;1(4):333-341.
65. England TJ, Abaei M, Auer DP, et al. Granulocyte-colony stimulating factor for mobilizing bone marrow stem cells in subacute stroke: the stem cell trial of recovery enhancement after stroke 2 randomized controlled trial. Stroke. 2012;43(2):405-411.

66. Jendelová P, Herynek V, Urdzíková L, et al. Magnetic resonance tracking of transplanted bone marrow and embryonic stem cells labeled by iron oxide nanoparticles in rat brain and spinal cord. J Neurosci Res. 2004;76(2):232-243.

67. Rice HE, Hsu EW, Sheng H, et al. Superparamagnetic iron oxide labeling and transplantation of adipose-derived stem cells in middle cerebral artery occlusion-injured mice. AJR Am J Roentgenol. 2007;188(4): 1101-1108.

68. Kim D, Chun BG, Kim YK, et al. In vivo tracking of human mesenchymal stem cells in experimental stroke. Cell Transplant. 2008;16(10): 1007-1012.

69. Walczak P, Zhang J, Gilad AA, et al. Dual-modality monitoring of targeted intraarterial delivery of mesenchymal stem cells after transient ischemia. Stroke. 2008;39(5):1569-1574.

70. Song M, Kim Y, Kim Y, et al. MRI tracking of intravenously transplanted human neural stem cells in rat focal ischemia model. Neurosci Res. 2009;64(2):235-239.

71. Gutiérrez-Fernández M, Rodríguez-Frutos B, Alvarez-Grech J, et al. Functional recovery after hematic administration of allogenic mesenchymal stem cells in acute ischemic stroke in rats. Neuroscience. 2011;175:394-405.

72. Riegler J, Liew A, Hynes SO, et al. Superparamagnetic iron oxide nanoparticle targeting of MSCs in vascular injury. Biomaterials. 2013;34(8): 1987-1994.

73. Vandeputte C, Thomas D, Dresselaers T, et al. Characterization of the inflammatory response in a photothrombotic stroke model by MRI: implications for stem cell transplantation. Mol Imaging Biol. 2011;13(4):663-671.

74. Hoehn M, Küstermann E, Blunk J, et al. Monitoring of implanted stem cell migration in vivo: a highly resolved in vivo magnetic resonance imaging investigation of experimental stroke in rat. Proc Natl Acad Sci US A. 2002;99(25):16267-16272.

75. Lu SS, Liu S, Zu QQ, et al. In Vivo MR Imaging of Intraarterially Delivered Magnetically Labeled Mesenchymal Stem Cells in a Canine. Stroke Model. PLoS One. 2013;8(2):e54963.

76. Liu Huan, Jiasong Cao, Haihong Zhang, et al. Folic acid stimulates proliferation of transplanted neural stem cells after focal cerebral ischemia in rats. J Nutr Biochem. 2013;24(11):1817-1822.

77. Guo RN, Cao N, Zhang F, et al. Controllable labelling of stem cells with a novel superparamagnetic iron oxide-loaded cationic nanovesicle for MR imaging. Eur Radiol. 2012;22(11):2328-2337.

78. Wu K, Taki Y, Sato K, Qi H, Kawashima R, Fukuda H. A longitudinal study of structural brain network changes with normal aging. Front Hum Neurosci. 2013;7:113.

79. Kaliman P, Párrizas M, Lalanza JF, Camins A, Escorihuela RM, Pallàs M. Neurophysiological and epigenetic effects of physical exercise on the aging process. Ageing Res Rev. 2011;10(4):475-486.

80. Mora F. Successful brain aging: plasticity, environmental enrichment, and lifestyle. Dialogues Clin Neurosci. 2013;15(1):45-52.

81. Joseph J, Cole G, Head E, Ingram D. Nutrition, brain aging, and neurodegeneration. J Neurosci. 2009;29(41):12795-12801.

82. Jakovcevski M, Akbarian S. Epigenetic mechanisms in neurological disease. Nat Med. 2012;18(8):1194-1204.

83. Lovatel GA, Elsner VR, Bertoldi K, et al. Treadmill exercise induces age-related changes in aversive memory, neuroinflammatory and epigenetic processes in the rat hippocampus. Neurobiol Learn Mem. 2013;101:94-102.

84. Vera E, Bernardes de Jesus B, Foronda M, Flores JM, Blasco MA. Telomerase reverse transcriptase synergizes with calorie restriction to increase health span and extend mouse longevity. PLoS One. 2013;8(1):e53760.

85. Feng Z, Gao F. Stem cell challenges in the treatment of neurodegenerative disease. CNS Neurosci Ther. 2012;18(2):142-148. 
86. Borlongan CV, Glover LE, Tajiri N, Kaneko Y, Freeman TB. The great migration of bone marrow-derived stem cells toward the ischemic brain: therapeutic implications for stroke and other neurological disorders. Prog Neurobiol. 2011;95(2):213-228.

87. Seo JH, Cho SR. Neurorestoration induced by mesenchymal stem cells: potential therapeutic mechanisms for clinical trials. Yonsei Med J. 2012;53(6):1059-1067.

88. Deng J, Petersen BE, Steindler DA, Jorgensen ML, Laywell ED. Mesenchymal stem cells spontaneously express neural proteins in culture and are neurogenic after transplantation. Stem Cells. 2006;24(4):1054-1064.

89. Joyce N, Annett G, Wirthlin L, Olson S, Bauer G, Nolta JA. Mesenchymal stem cells for the treatment of neurodegenerative disease. Regen Med. 2010;5(6):933-946.

90. Majumdar S, Zoghbi SS, Gore JC. Regional differences in rat brain displayed by fast MRI with superparamagnetic contrast agents. Magn Reson Imaging. 1988;6(6):611-615.

91. Guenoun J, Ruggiero A, Doeswijk G, Janssens, et al. In vivo quantitative assessment of cell viability of gadolinium or iron-labeled cells using MRI and bioluminescence imaging. Contrast Media Mol Imaging. 2013;8(2):165-174.

92. Jasmin, Torres AL, Nunes HM, et al. Optimized labeling of bone marrow mesenchymal cells with superparamagnetic iron oxide nanoparticles and in vivo visualization by magnetic resonance imaging. J Nanobiotechnology. 2011;9:4.

93. Mamani JB, Pavon LF, Miyaki LA, et al. Intracellular labeling and quantification process by magnetic resonance imaging using iron oxide magnetic nanoparticles in rat C6 glioma cell line. Einstein (Sao Paulo). 2012;10(2):216-221.
94. Sibov TT, Miyaki LA, Mamani JB, et al. Evaluation of umbilical cord mesenchymal stem cell labeling with superparamagnetic iron oxide nanoparticles coated with dextran and complexed with Poly-L-lysine. Einstein (Sao Paulo). 2012;10(2):180-188.

95. Eve DJ, Fillmore RW, Borlongan CV, Sanberg PR. Stem cell research in cell transplantation: sources, geopolitical influence, and transplantation. Cell Transplant. 2010;19(11):1493-1509.

96. Inden M, Takata K, Nishimura K, et al. Therapeutic effects of human mesenchymal and hematopoietic stem cells on rotenone-treated parkinsonian mice. J Neurosci Res. 2013;91(1):62-72.

97. McGuckin CP, Jurga M, Miller AM, et al. Ischemic brain injury: a consortium analysis of key factors involved in mesenchymal stem cell-mediated inflammatory reduction. Arch Biochem Biophys. 2013;534(1-2):88-97.

98. Janssen H, Speare S, Spratt NJ, et al. Exploring the efficacy of constraint in animal models of stroke: meta-analysis and systematic review of the current evidence. Neurorehabil Neural Repair. 2013;27(1):3-12.

99. Livingston-Thomas JM, Tasker RA. Animal models of post-ischemic forced use rehabilitation: methods, considerations, and limitations. Exp Transl Stroke Med. 2013;5(1):2.

100. Mazzini L, Vercelli A, Ferrero I, Boido M, Cantello R, Fagioli F. Transplantation of mesenchymal stem cells in ALS. Prog Brain Res. 2012;201:333-359.

101. Bai L, Hecker J, Kerstetter A, Miller RH. Myelin repair and functional recovery mediated by neural cell transplantation in a mouse model of multiple sclerosis. Neurosci Bull. 2013;29(2):239-250.
International Journal of Nanomedicine

\section{Publish your work in this journal}

The International Journal of Nanomedicine is an international, peerreviewed journal focusing on the application of nanotechnology in diagnostics, therapeutics, and drug delivery systems throughout the biomedical field. This journal is indexed on PubMed Central, MedLine, CAS, SciSearch $\AA$, Current Contents ${ }^{\circledR} /$ Clinical Medicine,

\section{Dovepress}

Journal Citation Reports/Science Edition, EMBase, Scopus and the Elsevier Bibliographic databases. The manuscript management system is completely online and includes a very quick and fair peer-review system, which is all easy to use. Visit http://www.dovepress.com/ testimonials.php to read real quotes from published authors. 